\title{
Delaware Basin Monitoring Annual Report
}

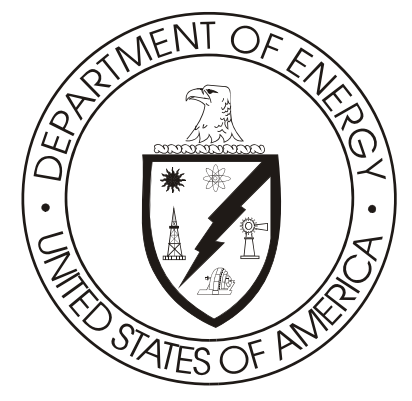

September 2005

\section{United States Department of Energy Waste Isolation Pilot Plant}

Carlsbad Field Office

Carlsbad, New Mexico 


\title{
Delaware Basin Monitoring Annual Report
}

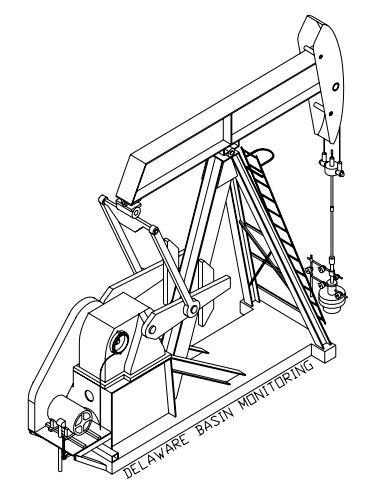

September 2005

\section{United States Department of Energy Waste Isolation Pilot Plant}

\author{
Carlsbad Field Office \\ Carlsbad, New Mexico \\ Prepared for \\ the Department of Energy by \\ Washington Regulatory \& Environmental Services \\ David Hughes \\ Delaware Basin Drilling Surveillance Program
}




\section{Table of Contents}

1.0 Delaware Basin Drilling Surveillance Program 1

$\begin{array}{lll}2.0 & 2005 \text { Updates } & 2\end{array}$

2.1 Miscellaneous Drilling Information 2

2.1.1 Drilling Techniques 3

2.1.2 Drilling Fluids 4

2.1.3 Air Drilling 4

2.2 Shallow Drilling Events 6

$\begin{array}{lll}2.3 & \text { Deep Drilling Events } & 6\end{array}$

2.4 Past Drilling Rates 7

$2.5 \quad$ Current Drilling Rate 7

2.5.1 Nine-Township Area Drilling Activities 8

2.5.2 Drilling Activities Outside the Nine-Township Area 8

2.6 Castile Brine Encounters 8

2.7 Borehole Permeability Assessment - Plugging Practices 9

2.8 Seismic Activity in the Delaware Basin 11

2.9 Secondary and Tertiary Recovery 11

2.9.1 Nine-Township Area Injection Wells 12

2.9.2 Nine-Township Area Salt Water Disposal Wells 12

2.10 Pipeline Activity 12

2.11 Mining 13

2.11.1 Potash Mining 13

2.11.2 Sulfur Extraction $\quad 14$

$\begin{array}{ll}2.11 .3 \text { Solution Mining } & 14\end{array}$

2.12 New Drilling Technology 15

3.0 Survey of Well Operators for Drilling Information 15

4.0 Summary - 2005 Delaware Basin Drilling Surveillance Program 16

$\begin{array}{lll}\mathbf{5 . 0} & \text { References } & 17\end{array}$ 


\section{List of Figures}

Figure $1 \quad$ WIPP Site, Delaware Basin, and Surrounding Area 18

Figure 2 Typical Well Structure and General Stratigraphy Near the WIPP Site 19

Figure $3 \quad$ Oil and Gas Wells Within One Mile of the WIPP Site 20

Figure $4 \quad$ Typical Borehole Plug Configurations in the Delaware Basin $\quad 21$

Figure $5 \quad$ Typical Injection or Salt Water Disposal Well (SWD) 22

Figure $6 \quad$ Active Injection and SWD Wells in the Nine-Township Area 23

Figure $7 \quad$ Potash Mining in the Vicinity of the WIPP Site 24

Figure 8 Active Brine Well Locations in the Delaware Basin 25

\section{List of Tables}

Table $1 \quad$ Nine-Township Area Casing Sizes 26

Table $2 \quad$ Nine-Township Area Bit Sizes 26

Table 3 Air-Drilled Wells in the New Mexico Portion of the Delaware Basin 27

Table $4 \quad$ Shallow Well Status in the Delaware Basin 28

Table $5 \quad$ Deep Well Status in the Delaware Basin 29

Table $6 \quad$ Past Drilling Rates for the Delaware Basin 30

Table $7 \quad$ Castile Brine Encounters in the Vicinity of the WIPP Site 31

Table $8 \quad$ Plugged Well Information 33

Table $9 \quad$ Plugging Summary by Well Type 36

Table $10 \quad$ Seismic Activity in the Delaware Basin 37

Table $11 \quad$ Nine-Township Injection and SWD Well Information 38

Table 12 Brine Well Status in the Delaware Basin 40 


\subsection{Delaware Basin Drilling Surveillance Program}

The Delaware Basin Drilling Surveillance Program (DBDSP) is designed to monitor drilling activities in the vicinity of the Waste Isolation Pilot Plant (WIPP). This program is based on Environmental Protection Agency (EPA) criteria. The EPA environmental radiation protection standards for the management and disposal of spent nuclear fuel, high-level and transuranic radioactive wastes are codified in Title 40 Code of Federal Regulations (CFR) Part 191 (EPA 1993). Subpart B of the standard addresses the disposal of radioactive waste. The standard requires the Department of Energy (DOE) to demonstrate the expected performance of the disposal system using a probabilistic risk assessment or performance assessment (PA). The results of the PA must show that the expected repository performance will not result in the release of radioactive material above limits set by the EPA's standard. This assessment must include the consideration of inadvertent drilling into the repository at some future time.

In 40 CFR Part 194 (EPA 1996), the EPA defined the geographical area for the evaluation of the historical rate of drilling for resources, as the Delaware Basin. This same area is to be used for monitoring drilling and drilling-related activities. The definition of the Delaware Basin in 40 CFR § 194.2 is:

"Delaware Basin means those surface and subsurface features which lie inside the boundary formed to the north, east and west of the [WIPP] disposal system, by the innermost edge of the Capitan Reef, and formed, to the south, by a straight line drawn from the southeastern point of the Davis Mountains to the most southwestern point of the Glass Mountains.”

The Delaware Basin, depicted in Figure 1, includes all or part of Brewster, Culberson, Jeff Davis, Loving, Pecos, Reeves, Ward, and Winkler counties in west Texas, and portions of Eddy and Lea counties in southeastern New Mexico.

The DOE continues to provide surveillance of the drilling activity in the Delaware Basin in accordance with the criteria established in 40 CFR Part 194. This will continue until the DOE and the EPA mutually agree no further benefit can be gained from continued surveillance. The results of the ongoing surveillance will be used to determine if a significant and detrimental change has occurred that would affect the performance of the disposal system.

The Delaware Basin Drilling Surveillance Plan (WP 02-PC.02) places specific emphasis on the nine-township area that includes the WIPP Site and provides data to build on the information presented in Appendix DEL of the Compliance Certification Application (CCA) (DOE 1996) and Appendix DATA of the Compliance Recertification Application (CRA) (DOE 2004). 


\section{$2.0 \quad 2005$ Updates}

The PA is required by regulation to consider disturbed case scenarios that include intrusions into the repository by inadvertent and intermittent drilling for resources. The probability of these intrusions is based on a future drilling rate of 46.8 boreholes per square kilometer per 10,000 years which was established for the 1996 CCA in Appendix DEL and 52.5 boreholes per square kilometer for the 2004 CRA in Appendix DATA. These rates are based on consideration of the record of drilling events in the Delaware Basin for the most recent 100-year period. The DOE models multiple types of human intrusion scenarios in the PA. These include both single intrusion events and combinations of multiple boreholes.

Two different types of boreholes are considered: (1) those that penetrate a pressurized brine reservoir in the underlying Castile Formation and (2) those that do not. While the presence of pressurized brine under the repository is speculative, it cannot be completely ruled out based on available information. The primary consequence of contacting pressurized brine is the introduction of an additional source of brine beyond that which is assumed to be released into the repository from the Salado Formation. The human intrusion scenario models are based on extensive field data sets collected by the DOE. The DBDSP collects the drilling-related data to be used for future PA calculations. The data have been continuously collected from the time of the 1996 submittal of the CCA and include specific wells drilled during the last year in the New Mexico portion of the Delaware Basin, specifically that of the nine-township area immediately surrounding the WIPP Site. These data are summarized in the following sections.

\subsection{Miscellaneous Drilling Information}

The EPA provided criteria in 40 CFR \$194.33(c) to address the consideration of drilling in the PA. These criteria led to the formulation of conceptual models that incorporate the effects of these activities. The conceptual models use parameter values as documented in Appendix DEL of the CCA, such as:

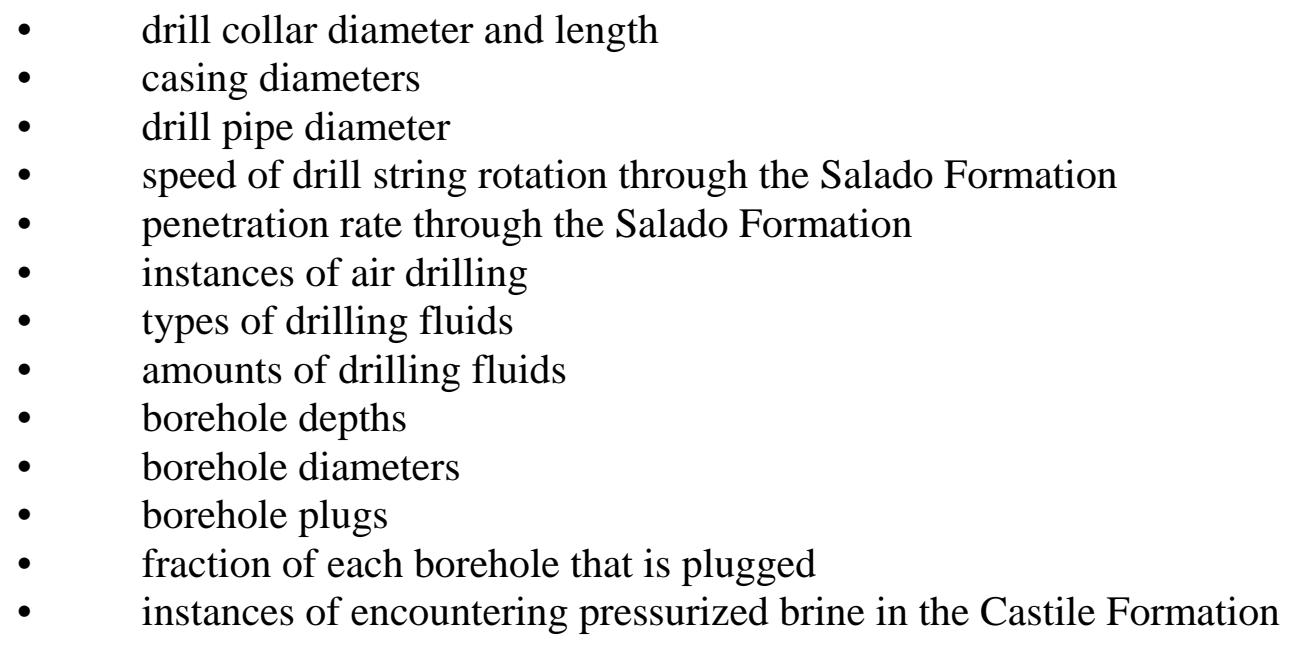


The DBDSP data set includes the final borehole depth for all wells drilled in the Delaware Basin. Borehole depths range from 19 feet to 25,201 feet. The 19-foot hole is an exhaust shaft monitoring well located on the WIPP Site, and the 25,201-foot hole is a gas well located in Texas. Borehole depths in the immediate vicinity of the WIPP Site typically range from 7,750 feet to 9,000 feet for oil wells and 13,000 feet to 16,000 feet for gas wells.

The diameter of each well bore is more difficult to ascertain. The DBDSP data set included the casing size and depth for each section of the hole (Table 1). Drill bit size is not a reportable element, although hole sizes are reported on Sundry notices (miscellaneous forms) maintained by the New Mexico Oil Conservation Division (NMOCD). The casing size or hole size is used to determine the size of the bit used to drill that particular section of the well. Currently, the most common bit sizes are $171 / 2 \mathrm{in}$. for the surface section, $11 \mathrm{in}$. for the intermediate section, and $77 / 8$ in. for the production section of the hole. Table 2 shows the documented bit sizes used in drilling wells in the nine-township area during the past year.

In the early days of well drilling, the $12 \frac{1}{4} \mathrm{in}$. bit was popular with rotary drill operators for the surface section of the hole. In those days, the wells were much shallower and did not require the larger casing sizes. Most holes drilled at that time were two-string (string refers to the different size of casing in the wellbore) holes versus the three- and four-strings commonly used now. In the area of the WIPP Site, regulations in the area designated by the Secretary of Interior as the Known Potash Leasing Area (KPLA) require a three-string hole making the larger bit sizes more popular. The typical hole and casing sizes for a three-string well in the vicinity of the WIPP Site are shown in Figure 2.

When drilling a well, many factors come into play: the depth to be drilled, the geology of the substrata, the equipment being used, etc. In the early 1950s, it commonly took an average of 50 days to drill a well to depth. Today it takes approximately 20 days to drill a well to depth.

\subsubsection{Drilling Techniques}

The drilling techniques reported in Appendix DEL of the CCA are still being implemented by area drillers. There were a total of 204 hydrocarbon wells spudded, not necessarily completed, in the New Mexico portion of the Delaware Basin from September 1, 2004 through August 31, 2005. This number is derived from the databases maintained by the DBDSP. In reality, the number of new wells is higher; but the paperwork on some of the wells has not yet been filed with the NMOCD or will be filed after the writing of this report. Therefore, those wells are not included in the count listed above.

Rotary drilling rigs were used to drill all 204 wells. Some have been completed as oil wells, others as gas wells, while the rest are still in the process of being completed. Five wells were dry holes or junked and abandoned. All were conventionally drilled utilizing mud as a medium for circulation. Forty-four of these wells were in the nine-township area. The depths of the completed wells in the nine-township area range from 7,347 feet to 11,950 feet. Outside of the nine-township area the depths of the completed wells range from 3,200 feet to 16,600 feet. 
A technique used by operators to increase production is to drill a well horizontally after a target depth is reached, which allows for more of the wellbore area to be in the production zone. As reported in Appendix DEL, this technique is not often used in this area because of the increased costs (it adds to the drilling time). The DBDSP monitors directional and horizontally drilled wells only in the nine-township area. Four of the 44 new wells spudded during the last year in the nine-township area had horizontally drilled components. All four are located in T22S-R30ESections 13, 24, and 25 (See Figure 3).

\subsubsection{Drilling Fluids}

Employing a rotary rig for drilling involves the use of drilling fluids. Drilling fluid is commonly known as mud, which is the liquid circulated through the wellbore during rotary drilling and workover operations. In addition to its function of bringing cuttings to the surface, drilling mud cools and lubricates the bit and drill stem, protects against blowouts by holding back subsurface pressures, and deposits a mud cake on the wall of the borehole to prevent loss of fluids to the formation.

Typically, a driller will use fresh water and additives to drill the surface section of the hole which ends at the top of the Salado Formation. A change in drilling practices would necessitate a change in the application of drilling fluids. Within the KPLA of southeastern New Mexico, drillers are required under Title 19, Chapter 15, Order R-111-P of the New Mexico Administrative Code (NMAC) to use a saturated brine to drill through the salt formation which is usually called the intermediate section. This requirement is to keep the salt from washing out and making the hole larger than necessary. Once this section has been drilled and cased, the driller again changes to fresh water and additives to finish drilling the hole to depth.

\subsubsection{Air Drilling}

A method of hydrocarbon drilling not emphasized in CCA Appendix DEL is air drilling. As defined by the oil industry, air drilling is a method of rotary drilling using compressed air as the circulation medium. The conventional method of removing cuttings from the wellbore is to use a flow of water or drilling mud. In some cases, compressed air removes the cuttings with equal or greater efficiency. The rate of penetration is usually increased considerably when air drilling is used; however, a fundamental problem in air drilling is the penetration of formations

containing water, since the entry of water into the system reduces the ability of the air to remove cuttings.

Critics noted the air drilling scenario was not included by the DOE in the CCA and raised several issues: (1) air drilling technology is currently successfully used in the Delaware Basin, (2) air drilling is thought to be a viable drilling technology under the hydrological and geological conditions at the WIPP Site, and (3) air drilling could result in releases of radionuclides that are substantially greater than those considered by the DOE in the CCA. Considerable research on air drilling in the Delaware Basin has determined that although air drilling is a common method of drilling wells, it is not practiced in the vicinity of the WIPP Site because (1) it is against R- 
111-P regulations to drill with anything but saturated brine through the salt formation in the KPLA; (2) it is not economical to drill with air when a driller has to use saturated brine for the intermediate section; and (3) if water is encountered prior to or after drilling the salt formation, the driller would have to convert to a conventional system of drilling.

Additional information was provided to EPA Air Docket No. A-93-02, IV-G-7. In this information, the following was provided:

\begin{abstract}
The well record search has continued and now includes information from the entire New Mexico portion of the Delaware Basin. Within the nine-townships surrounding the WIPP, the records showed no evidence of air drilling. One possible exception to this may be the Lincoln Federal \#1. This well is said to have been air drilled due to a loss of circulation at a depth of 1290 feet, but this has not been verified. The records associated with the Lincoln Federal \#1 do not contain any evidence of air drilling. Rather, this information is based on verbal communications with the operating and drilling companies involved with the well. Nonetheless, the Lincoln Federal \#1 may have been drilled with air, although it was not a systematic use of the technology. Air drilling at this well was used from 2984' to 4725' merely as a mitigative attempt to continue drilling to the next casing transition depth. After this casing transition, mud drilling was used for the remainder of the hole.

The area of the expanded search contains 3,756 boreholes. Of these, 407 well files were unavailable for viewing (in process), therefore, 3,349 well files constitute the database. Among these wells, 11 instances of air drilling were found in which any portion of the borehole was drilled with air. Only 7 of these were drilled through the Salado Formation at the depth of the repository. This results in a frequency of $7 / 3349$, or 0.0021 . This value is conservative in that it includes the Lincoln Federal \#1, and four other wells which were proposed to be drilled with air, but no subsequent verification of actual drilling exists in the records.
\end{abstract}

In the Final Rule, the EPA ruled air drilling did not have to be considered for PA; however, the DBDSP will continue to monitor for instances of air drilling.

During the summer of 1999, another search of these same records was conducted as a follow up to the original research. This search of the records was used as a quality assurance check of the original search. The database consisted of 3,810 boreholes with only 12 records unavailable for viewing. This search added five more wells with indications of some portion of the hole being drilled with air. None were located in the nine-township area or were air drilled through the Salado Formation. Of the five wells added to the count, one (the Sheep Draw "28" Federal \#13) had the first 358 feet air drilled while the other four had the conductor pipe drilled with air which consists of the first 40 feet of the borehole and is not usually reported in the drilling process. The conductor casing is typically drilled, set in place, and cemented prior to setting up the rotary drilling rig that will eventually drill the well.

The records on the new wells spudded during the last year (September 1, 2004 through August 31, 2005) are being checked as they become available at the NMOCD Internet site for instances of air drilling. The records can be submitted to the NMOCD offices as late as two years after the well has been drilled. The record review is an ongoing process conducted on a continuing basis. None of the records reviewed to date have indicated any additional instances of air drilling. As 
was presented in the testimony (public hearings conducted by the EPA on WIPP certification) and continues to be validated by ongoing review, air drilling is not a common practice in the vicinity of the WIPP Site. Table 3 shows all of the known indications of air drilling that have occurred in the New Mexico portion of the Delaware Basin.

\subsection{Shallow Drilling Events}

One of the criteria of 40 CFR Part 194 is that the CCA must adequately and accurately characterize the frequency of shallow drilling within the Delaware Basin, as well as, support the assumptions and determinations, particularly those that limit consideration of shallow drilling events based on the presence of resources of similar type and quantity found in the controlled area. The DOE concluded in Appendix SCR that shallow drilling could be removed from PA consideration based on low consequence. As a result, the DOE did not include shallow drilling in its PA drilling rate calculations and did not include any reduction in shallow drilling rates during the active and passive institutional control periods. In Compliance Application Review Document (CARD) 32, the EPA accepted the DOE's finding that shallow drilling would be of low consequence to repository performance and need not be included in the PA.

Although the EPA has agreed shallow drilling can be eliminated from the PA and need not be tracked, the DBDSP collects data on all wells reported to be drilled within the boundaries of the Delaware Basin. The program makes no distinctions between shallow and deep drilling events except when calculating the intrusion rate for deep drilling. Information on all wells drilled is vital for trending future activities. Table 4 shows a breakdown of the various types and number of shallow wells located within the Delaware Basin.

\subsection{Deep Drilling Events}

In accordance with the criteria, the DOE used the historical rate of drilling for resources in the Delaware Basin to calculate a future drilling rate. In particular, in calculating the frequency of future deep drilling, 40 CFR §194.33(b)(3)(i) (EPA 1996) provided the following criteria to the DOE:

Identify deep drilling that has occurred for each resource in the Delaware Basin over the past 100 years prior to the time at which a compliance application is prepared.

The DOE used the historical record of deep drilling for resources below 2,150 feet that has occurred over the past 100 years in the Delaware Basin. This was chosen because it is the depth of the repository, and the repository is not directly breached by boreholes less than this depth. In the past 100 years, deep drilling occurred for oil, gas, potash, and sulfur. These drilling events were used in calculating a rate for deep drilling for the PA as discussed in Appendix DEL of the CCA. The period of calculation used was from 1896 through June 1995. Historical drilling for purposes other than resource exploration and recovery (such as WIPP Site investigation) were excluded from the calculation in accordance with criteria provided in 40 CFR §194.33. 
In the Delaware Basin, deep drilling events are usually associated with oil and gas drilling. Commercial sources and visits to the NMOCD offices and Internet site are used to identify these events. The DBDSP collects data on all drilled wells within the Delaware Basin, making no distinction between resources. Two separate databases are maintained on hydrocarbon wells, one for Texas and one for New Mexico. As information on wells is acquired, it is entered into the individual databases. The Texas database contains information only on the current status of the well, when it was drilled, its location, who the operator is, and the total depth of the well. The Texas portion of the Delaware Basin is used only for calculating the drilling rate. The database for the New Mexico portion of the Delaware Basin contains the same basic information as Texas along with all the information required for PA related drilling events.

The DBDSP continues to monitor all hydrocarbon drilling activity and any new potash, sulfur, water, or monitoring wells for deep-drilling events. Information from the drilling of these wells is added to the databases maintained for these separate resources. During the last year, there were 367 new wells added to the databases. Most of the wells were drilled for hydrocarbon extraction and almost all were deep-drilling events. Forty-four of these new wells are in the nine-township area immediately surrounding the WIPP Site. Table 5 shows the number and type of deep wells located in the Delaware Basin.

\subsection{Past Drilling Rates}

The EPA provided a formula for calculating the current drilling rate or intrusion rate when 40 CFR Part 194 was promulgated. The formula is as follows: number of holes drilled in the last 100 years times 10,000 years divided by the area of the Delaware Basin $\left(23,102.1 \mathrm{~km}^{2}\right)$ divided by 100 years (1897-1996, the year the CCA was submitted). Since shallow drilling events are of low consequence, only deep drilling events are applied to the formula. The DBDSP uses all deep drilling events of any resource (potash, oil, gas, water, etc.) to calculate the drilling or intrusion rate.

The drilling rates since the submittal of the CCA in 1996 are shown in Table 6. The large increase between 1996 and 1997 is the result of updating the databases with information from June 1995 through August 1997. Also, the 100-year window is considered a sliding window, in which 100 years worth of data are used each time the calculation is performed. As each new year's data are added, the oldest year's data are dropped. For example, the drilling rate was calculated in 1999 by using the data from 1900 through 1999. In 2000, the data from 1901 through 2000 was used to calculate the drilling rate.

\subsection{Current Drilling Rate}

The calculated intrusion or drilling rate for 2005 was derived from the information provided in Table 5. There were 12,819 boreholes deeper than 2,150 feet. Applying the formula results in the following: 12,819 boreholes $x 10,000$ years / 23,102.1 $\mathrm{km}^{2} / 100$ years. This results in a drilling or intrusion rate of 55.5 boreholes per $\mathrm{km}^{2}$ over 10,000 years. 
This is an increase from the 46.8 boreholes per $\mathrm{km}^{2}$ reported in the 1996 CCA. This number is anticipated to rise for several more years before it begins to drop. This is because of the 100year time frame used for drilling results. As new wells are added to the count, wells older than 100 years are dropped. It will be 2011 before any wells are dropped from the count while a number of new wells will be added due to ongoing oil and gas drilling activity, thus increasing the rate.

\subsubsection{Nine-Township Area Drilling Activities}

From September 1, 2004 to August 31, 2005, there were 44 new wells spudded in the ninetownship area immediately surrounding the WIPP Site. Six new wells were drilled in the onemile area surrounding the WIPP Site with all immediately to the west of the site. Figure 3 shows the status of all known hydrocarbon wells drilled within the one-mile area of the WIPP Site. Of the 44 new wells, 34 were drilled in Eddy County and ten in Lea County. Eleven of the wells were to the northeast and east of the site, six to the west of the site, while the rest were all south of the site. Devon Energy Production Company drilled the most new wells in the nine-township area with 20 wells. Pogo Producing Company had five new wells, and Yates Petroleum Corporation drilled eight new wells in the nine-township area during the last year. These three companies are the major producers in the area along with other companies such as, Strata Production Company, Bass Enterprises Production Company, Latigo Petroleum, Harvard Petroleum, Echo Production, Inc., and COG Operating, LLC.

\subsubsection{Drilling Activities Outside the Nine-Township Area}

In the New Mexico portion of the Delaware Basin outside of the nine-township area, there were 160 new wells spudded during the reporting period of September 1, 2004 through August 31, 2005. Of the 160 wells, 144 were located in Eddy County and 16 were in Lea County. Most of the wells drilled in the vicinity of Carlsbad tend to be gas wells and the ones drilled closer to the nine-township area are mostly oil wells when completed.

In the Texas portion of the Delaware Basin, 163 new wells were spudded during the reporting period. The DBDSP monitors drilling activities in portions of seven counties and all of one county (Loving). Most of the wells were drilled in Loving, Reeves, and Ward counties.

\subsection{Castile Brine Encounters}

WIPP PA included the assumption that a borehole results in the establishment of a flow path between the repository and a pressurized brine pocket that might be located beneath the repository in the Castile Formation. Research was performed in an attempt to verify this assumption. Studies recorded a total of 27 out of 620 wells ecountering pressurized brine in the Castile Formation; of these, 25 were hydrocarbon wells scattered over a wide area in the vicinity of the WIPP Site. The remaining wells, ERDA 6 and WIPP 12, were drilled in support of WIPP Site characterization. 
As indicated earlier, the search of the records performed in 1999 for instances of air drilling also looked for instances of pressurized brine. Although the search of the records noted a number of instances of encounters with sulfur water and brine water, none but the original 27 were found to have been pressurized brine encounters in the Castile Formation.

The DBDSP researches the well files of all new wells drilled in the New Mexico portion of the Delaware Basin each year looking for instances of encounters with pressurized brine. The program also sends out an annual survey to operators of new wells asking if they encountered pressurized brine during the drilling process. As of this report, none of the records reviewed indicated encounters with pressurized brine during the drilling of new wells spudded in the New Mexico portion of the Delaware Basin between September 2004 and August 2005.

Seven of the 497 wells drilled since the 1996 CCA have encountered Castile Brine. Six were picked up when WIPP Site personnel performing field work talked to area drillers. The other encounter was reported by an operator in the Annual Survey of area drillers. All the new encounters have been in areas where Castile Brine is expected to be encountered during the drilling process. Table 7 shows all known Castile Brine encounters in the vicinity of the WIPP Site.

\subsection{Borehole Permeability Assessment - Plugging Practices}

The hydrocarbon well plugging assumptions used for the borehole permeability assessment remain valid. The regulations in place during the submittal of the CCA and the CRA have not changed. The assessment will not change unless the regulations change to allow a different method of plugging. Regulations require the well be plugged in a manner that will permanently confine all oil, gas, and water in the separate strata in which they were originally found. These regulations require a notice of intent to plug from the operator. This notice includes a diagram of the well bore and the placement of the plugs. A 24-hour notice to the NMOCD or to the Bureau of Land Management (BLM) is required before plugging may commence.

Approximately 500 wells in the vicinity of the WIPP Site in are in the KPLA. Under R-111-P regulations, the operator is required to provide a solid cement plug through the salt section and any water-bearing horizon in addition to installing a bridge plug above the perforations. This requirement provides protection to mineralized potash areas and workings by requiring a continuous plug so that there is virtually no chance of flooding nearby mines either as they are developed or during their operation.

In the New Mexico portion of the Delaware Basin, the DBDSP retrieves a copy of the plugging report from the NMOCD Internet site when a well has been plugged and abandoned. This information is added to the records maintained by the DBDSP on each well drilled within the Delaware Basin. By maintaining records in such a fashion, should the regulations change and the plugging methods differ from what is now occurring, a trend would be noticed and the borehole permeability assessment revisited. Table 8 shows various plug information on the 
wells plugged and abandoned within the New Mexico portion of the Delaware Basin in the last year.

CCA Appendix MASS, Attachment 16-1 describes the development of a conceptual model for long-term performance of plugged boreholes. The study did not attempt to predict the effectiveness of plugs, but to identify the location and physical characteristics of plugs which might be important to performance assessment. Guidance in 40 CFR 194 states that "Performance assessments should assume that the permeability of sealed boreholes will be affected by natural processes, and should assume that the fraction of boreholes that will be sealed by man equals the fraction of boreholes which are currently sealed in the Delaware Basin." The criteria also state that “...drilling practices will remain as those of today.” Only wells plugged in the New Mexico portion of the Delaware Basin were used for the study and only wells drilled after 1988, when the current plugging regulation went into effect, were used. The results of this study indicated that PA should assume a 100\% plugging frequency.

To determine the typical configuration and composition of a borehole plug, the study considered both current drilling and plugging practices to arrive at a model depicting six different types of plugging configurations (see Figure 4):

Type I Plugs will be located at the transition between the surface and intermediate casings and the transition between the intermediate and production casings. This area is usually the top of the Salado Formation and the bottom of the Castile Formation, roughly 800 feet and 4,000 feet below the surface, respectively.

Type II This plugging configuration has a portion of the production casing salvaged. Where the production casing was cut a plug must be installed. If a plug occurs between 2,150 feet and 2,700 feet (above the hypothetical brine pocket) and the other plugs occur at the top of the Salado Formation and below the Castile Formation, it is considered a Type II configuration.

Type III This configuration is the same as above except the removed production casing plug occurs above 2,150 feet.

Type IV Extra plugs, in addition to those of Type II, have been emplaced above 2,150 feet.

Type V The minimum regulatory requirements require a surface plug and a plug occurring at the bottom, provided no water-bearing zones were encountered. This type of plugging configuration is not common.

Type VI This configuration has a solid cement plug through a significant portion of the salt section. This configuration, like the others, may have additional plugs above and below the salt-section plug. 
There were nine hydrocarbon wells, with two located in the R-111-P area, plugged in the ninetownship area during the reporting period and 16 others outside the nine-township area. Twenty of the 24 wells will be used in the permeability assessment update (see Table 9). Two were shallow wells and two had no plugging reports available at the time of this report.

\subsection{Seismic Activity in the Delaware Basin}

The DBDSP records in a database and on a map known seismic events occurring in Southeast New Mexico and West Texas, specifically in the Delaware Basin. This information is provided every quarter in a report from New Mexico Institute of Mining and Technology, Socorro, New Mexico, utilizing data from an array of nine seismographs in the vicinity of the WIPP Site.

During the reporting period there were no seismic events recorded in the Delaware Basin. Table 10 provides information on recorded events which have occurred in the Delaware Basin.

\subsection{Secondary and Tertiary Recovery}

Secondary recovery is defined by the oil industry as the first improved recovery method of any type applied to a reservoir to produce oil not recoverable by primary recovery methods. Waterflooding is one such method. This method involves pumping water through the existing perforations in a well. As the water is pumped into a formation, it stimulates production of oil or gas in other nearby wells. This is a proven method of recovering hydrocarbons that otherwise would be economically unretrievable. Waterflooding has been a popular form of secondary recovery for over 40 years. Waterflooding can be accomplished by one injection well or several injection wells in the immediate vicinity of other producing wells.

In the New Mexico portion of the Delaware Basin, there are three major waterflood projects and several one and two injection well operations. One of the major waterflood projects in the area is the El Mar, located in T26S-R32E, on the Texas border. At one time, this project (currently operated by Sahara Operating) had 31 permitted injection wells. Currently, there are only two wells actively injecting water. The remaining wells are either shut-in or plugged and abandoned. The operation for the El Mar project has not changed during the last year. The Paduca waterflood project, located in T25S-R32E, has 19 permitted injection wells with ten (same as last year) injecting water into the formation. The third major waterflood project in this area (Indian Draw), located in T22S-R28E, is currently injecting into six of its permitted wells. At this time last year, this facility was not injecting into any of the ten permitted wells.

Tertiary recovery is defined by the oil industry as the use of any improved recovery method to remove additional oil after secondary recovery. One method of tertiary recovery practiced in the industry, where conditions permit, is the injection of carbon dioxide $\left(\mathrm{CO}_{2}\right)$ into the formation. This consists of injecting a prescribed amount of $\mathrm{CO}_{2}$ into the reservoir followed by an injection of water and a subsequent injection of $\mathrm{CO}_{2}$. At the time of this report, there are no known $\mathrm{CO}_{2}$ injection wells or tertiary recovery projects being operated in the vicinity of the WIPP Site, 
although several are being operated by oil companies in the Texas portion of the Delaware Basin.

\subsubsection{Nine-Township Injection Wells}

Secondary recovery projects occurring in the nine-township area are on a small scale. There are six injection wells, no change from this time last year, located in the nine-township area surrounding the WIPP Site. ConocoPhillips operates two injection wells, James "A" \#3 and \#12, located in section 2-T22S-R30E, northwest of the site. Both are active and injecting an average of 46,000 bbls per month. Both first injected water in the early 1990s. The other four injection wells are operated by Pogo Producing Company. The Neff Federal \#3 is located in section 25T22S-R31E. This well went on-line in 1995 and has injected approximately 5,792,020 barrels $(4,971,521$ barrels this time last year) of water at an average of 68,000 bbls per month. The Pure Gold “B” Federal \#20 (23S-31E-20) has injected 808,517 barrels to date. The third Pogo well (Prize Federal \#4 located in 22S-32E-27) has injected 833,362 barrels to date. The fourth Pogo well (State "2" \#5 located in 22S-31E-02) was permitted in 2003 and recently began injecting. It has injected 288,582 barrels to date. All six wells are injecting into the Brushy Canyon Formation of the Delaware Mountain Group at a depth of approximately 7,200 feet. Figure 5 shows a typical injection or salt water disposal well configuration.

\subsubsection{Nine-Township Salt Water Disposal Wells}

The most common type of injection well is for the disposal of brine water coming from the producing formation in oil and gas wells. Figure 6 shows the location of active injection and salt water disposal wells in the nine-township area. Most producing oil and gas wells produce water along with oil or gas. Salt Water Disposal (SWD) wells have become necessary as a result of the EPA's ruling that formation water may no longer be disposed of on the surface. The oil companies now dispose of this water by injecting it into approved SWD wells.

There are currently 39 SWD wells, an increase of three over the last year, operated by 13 companies (12 companies in 2004) located in the nine-township area surrounding the WIPP Site. Two operators, Devon Energy and Pogo Producing, operate the majority of the SWD wells. Injection depths range from 3,800 feet to 8,200 feet. During the last year, all operated within their maximum permitted injection pressure. The volume of disposed brine water depends on the number of producing wells maintained by the operator in the immediate vicinity of the SWD well. Table 11 provides disposal information on all SWD and injection wells in the ninetownship area.

\subsection{Pipeline Activity}

Pipeline activity is monitored in the nine-township area, specifically within a five mile radius of the WIPP Site. Only pipelines of permanent construction, such as buried rigid metal pipelines, are of concern to the DBDSP. Many oil, gas, and SWD wells are connected to tank batteries by gathering systems constructed of poly flowlines (flexible plastic pipe) that may or may not be 
buried. These flowlines are semi-permanent. When they are no longer needed, they are removed for use elsewhere. This type of pipeline activity is not monitored by the DBDSP. Metal pipeline activity is of interest because of its longevity thus requiring the locations of these pipelines to be documented. Only natural gas and water pipelines are located within the immediate vicinity of the WIPP Site. The natural gas pipelines are owned and operated by three companies, El Paso Natural Gas Company, Natural Gas Pipeline Company of America, and Transwestern Pipeline Company.

One type of pipeline activity of major concern to the DBDSP is $\mathrm{CO}_{2}$ pipelines. A form of tertiary recovery of oil, discussed previously, uses $\mathrm{CO}_{2}$. An indicator of this form of recovery would be the construction of a $\mathrm{CO}_{2}$ pipeline in the area. Currently, there are no $\mathrm{CO}_{2}$ pipelines within the New Mexico portion of the Delaware Basin. The nearest $\mathrm{CO}_{2}$ pipeline is located south of the WIPP Site in the Texas portion of the Delaware Basin.

\subsection{Mining}

Resources found in the Delaware Basin that can be mined are potash, sulfur, caliche, gypsum, and halite. Potash and sulfur are present in quantities large enough to be mined profitably. Only caliche, of the other resources available, is economically extracted from the earth in conventional mining methods. Caliche is mainly used in the construction of pads for oil and gas well drilling rigs.

\subsubsection{Potash Mining}

Potash mining in the immediate vicinity of the WIPP Site continues as reported in Appendix DEL of the CCA and Appendix DATA of the CRA. Figure 7 shows the location and the extent of the potash mines in the vicinity of the WIPP Site. There have been several changes to the companies that operate in the area, most notably, only two potash mining companies remain in operation. No plans have been promulgated by either company to sink new shafts or develop new mines.

In August 1996, Mississippi Potash (a subsidiary of Mississippi Chemical Corporation) purchased all the assets of New Mexico Potash Corporation and Eddy Potash, Inc. These plants were renamed Mississippi East and Mississippi North, respectively. In early 2004, Mississippi Potash sold its Carlsbad properties to Intrepid Mining LLC, a Denver based mining company. Eddy Potash is currently shut down.

The other potash producer in the area is Mosaic, formerly known as IMC Kalium Potash, which was a wholly-owned subsidiary of IMC Global. Western Ag-Minerals was purchased by IMC Global September 1997. This acquisition doubled the potash reserves for IMC Kalium. IMC Global merged with Freeport-McMoRan, a major world potash producer, in December 1997 with IMC Global as the surviving entity in the transaction. 


\subsubsection{Sulfur Extraction}

The only viable sulfur mining activity within the Delaware Basin was conducted by FreeportMcMoRan Sulphur, Inc., a wholly-owned subsidiary of McMoRan Exploration Company. The mine is located in Culberson County, Texas. The mine recovered sulfur utilizing the Frasch process (solution mining) which consists of a hole drilled into the sulfur bearing formation and then cased. The next step involves the placement of three concentric pipes within the protective casing to facilitate pumping superheated water down the hole, melting the sulfur, and recovering the molten sulfur to the surface. The Culberson mine was operated until it permanently ceased production on June 30, 1999. Abandonment and salvage operations continued until early summer of 2000.

Recently, a number of sulfur exploration coreholes were found in the BLM records. These coreholes were drilled in the late 1960s through the early 1980s in the Yeso Hills near Washington Ranch in the far southwest corner of the New Mexico portion of the Delaware Basin. These coreholes have yet to be added to the databases. All were shallow (less than 2,150 feet) drilling events that were conducted for various small operators. There have been no reports on whether any of the holes encountered sufficient quantities of mineable sulfur.

\subsubsection{Solution Mining}

Solution mining is the process by which water is injected into a mineral formation, circulated to dissolve the mineral, with the solution then pumped back to the surface where the minerals are removed from the water, usually by evaporation. There are several brine mines or wells in the area, three in New Mexico and nine in Texas (see Figure 8), that use this process to provide a brine solution for area drilling operators to use in the drilling process. These are all shallow wells using injected fresh water to dissolve salt into a brine solution.

Brine wells are classified as Class II injection wells. In the Delaware Basin, the process involves injecting fresh water through the wells into a salt formation to create a saturated brine solution, which is then extracted and used as a drilling agent when drilling a new well. These wells are tracked by the DBDSP on a continuing basis. Recently, while investigating the status of an idle Salt Water Disposal well at the OCD office, records were found within the file for the idle well, which indicated the presence of a permitted brine well (for retrieval) and an injection well to inject fresh water into the salt formation. The DBDSP records have been updated to list these new wells. Table 12 provides the status of brine wells in the Delaware Basin.

In early 1997, Mississippi Potash proposed to set up a pilot potash solution mining project at the former Eddy Potash mine located north of the WIPP Site and outside of the Delaware Basin. The BLM was provided with all of the necessary documentation to acquire a permit to operate the pilot project, but the project was postponed. In March 2002, Mississippi Potash again applied for a permit to operate a pilot potash solution mining project. In May 2002, the project was given approval to proceed by the BLM though the project has not been started. If the project is initiated, it will be approximately three acres in size. Although this project is outside 
of the Delaware Basin, it will be closely followed because of its importance to possible future activities of this kind that might occur in the Delaware Basin. There has been no change in the status of this project, it is still on hold. The new owner of Mississippi Potash, Intrepid Mining LLC, is reviewing its options for this project.

In the late 1960s, Conoco Minerals installed a pilot solution mining project on leases it held on the former AMAX property north of the Delaware Basin and the WIPP Site. The project was designed to test solution mining of potassium minerals and consisted of one injection well and three withdrawal wells, but the potash ore zone was deemed too thin to make this method viable.

\subsection{New Drilling Technology}

New drilling methods are researched by the DBDSP for impacts to the drilling methods currently used in the area. To date, no new methods of drilling have been identified or implemented in the vicinity of the WIPP Site.

\subsection{Survey of Well Operators for Drilling Information}

The WIPP Project surveys local well operators annually to acquire information on drilling practices normally not available on the Sundry notices supplied to the local state and federal offices by the operator or through commercial sources maintained by the DBDSP. Participation in the survey is voluntary. This survey requests information on other items of interest to the WIPP such as hydrogen sulfide $\left(\mathrm{H}_{2} \mathrm{~S}\right)$ encounters, Castile Brine encounters, or whether any section of the well was drilled with air. The DBDSP personnel review the records on all new wells drilled to look for the above data. The survey provides an additional source of information on drilling activities in the New Mexico portion of the Delaware Basin.

The first survey of area operators was performed July 1999 and had been sent out each July until 2004. An annual survey was not performed in July 2004 due to schedule conflicts with the Compliance Recertification Application. The survey for 2004 was moved to January 2005 and will be performed in January of each year. With this change, all results from the annual survey will be included in the annual report for that year as there will be nine months for surveys to be returned instead of two months.

In January 2005, 48 surveys were sent to six companies who had wells drilled during 2004 in the nine-township area immediately surrounding the WIPP Site. To date, no surveys have been returned. The following companies were mailed surveys: Bass Enterprises Production Co, Yates Petroleum Corporation, Devon Energy Production Company LP, Echo Production Inc., Harvard Petroleum, and Pogo Producing Co. 


\subsection{Summary - 2005 Delaware Basin Drilling Surveillance Program}

- $\quad$ Drilling practices continue to be the same.

- $\quad$ No new instances of air drilling.

- $\quad$ One Castile Brine encounter reported.

- $\quad$ The drilling rate has increased to 55.5 boreholes per square kilometer.

- $\quad$ IMC Kalium Potash changed its name to Mosaic.

- $\quad$ No change in solution mining activities.

- $\quad$ No change in injection and salt water disposal activities.

- $\quad$ Forty-four wells spudded in the nine-township area.

- $\quad$ One hundred sixty wells spudded outside the nine-township area in New Mexico.

- $\quad$ One hundred sixty-three wells spudded in the Texas portion of the Delaware Basin. 


\subsection{References}

B. L. Resources, Monthly Injection \& Saltwater Report for Southeast New Mexico, April 2005

New Mexico Bureau of Mines and Mineral Resources, 1995, Evaluation of Mineral Resources at the Waste Isolation Pilot Plant, Final Report, Vols. I-IV

New Mexico Institute of Mining and Technology, Seismicity of the WIPP Site for the Period April 1, 2005 through June 30, 2005, Socorro, New Mexico

New Mexico Junior College, 1995, Analytical Study of an Inadvertent Intrusion of the WIPP Site, Hobbs, New Mexico

Ross Kirkes, Current Drilling Practices Near WIPP, 1998. EPA Air Docket No. A-93-02, IV-G7, January 22, 1998

The University of Texas, Petroleum Extension Service, Division of Continuing Education, 1986, Fundamentals of Petroleum, Third Edition

The University of Texas, Petroleum Extension Service, Division of Continuing Education, 1991, A Dictionary for the Petroleum Industry, First Edition

U.S. Department of Energy, DOE/WIPP-99-2308, Rev. 5, Delaware Basin Monitoring Annual Report, September 2004

U.S. Department of Energy, 1996, Inadvertent Intrusion Borehole Permeability, Prepared by T.W. Thompson, W.E. Coons, J.L. Krumhansl, and F.D. Hansen

U.S. Department of Energy, DOE/WIPP-97-2240, Injection Methods: Current Practices and Failure Rates in the Delaware Basin, June 1997

U.S. Department of Energy, DOE/CAO-1996-2184, Title 40 CFR Part 191 Compliance Certification Application for the Waste Isolation Pilot Plant, October 1996

U.S. Department of Energy, DOE/WIPP 2004-3231, Title 40 CFR Part 191 Compliance Recertification Application for the Waste Isolation Pilot Plant, March 2004

U.S. Environmental Protection Agency (EPA), 1996. Title 40 CFR Part 194, Criteria for the Certification and Re-Certification of the Waste Isolation Pilot Plant's Compliance with the 40 CFR Part 191 Disposal Regulations

Washington TRU Solutions LLC, WP 02-PC.02, Rev. 1, Delaware Basin Drilling Surveillance Plan, July 2004 


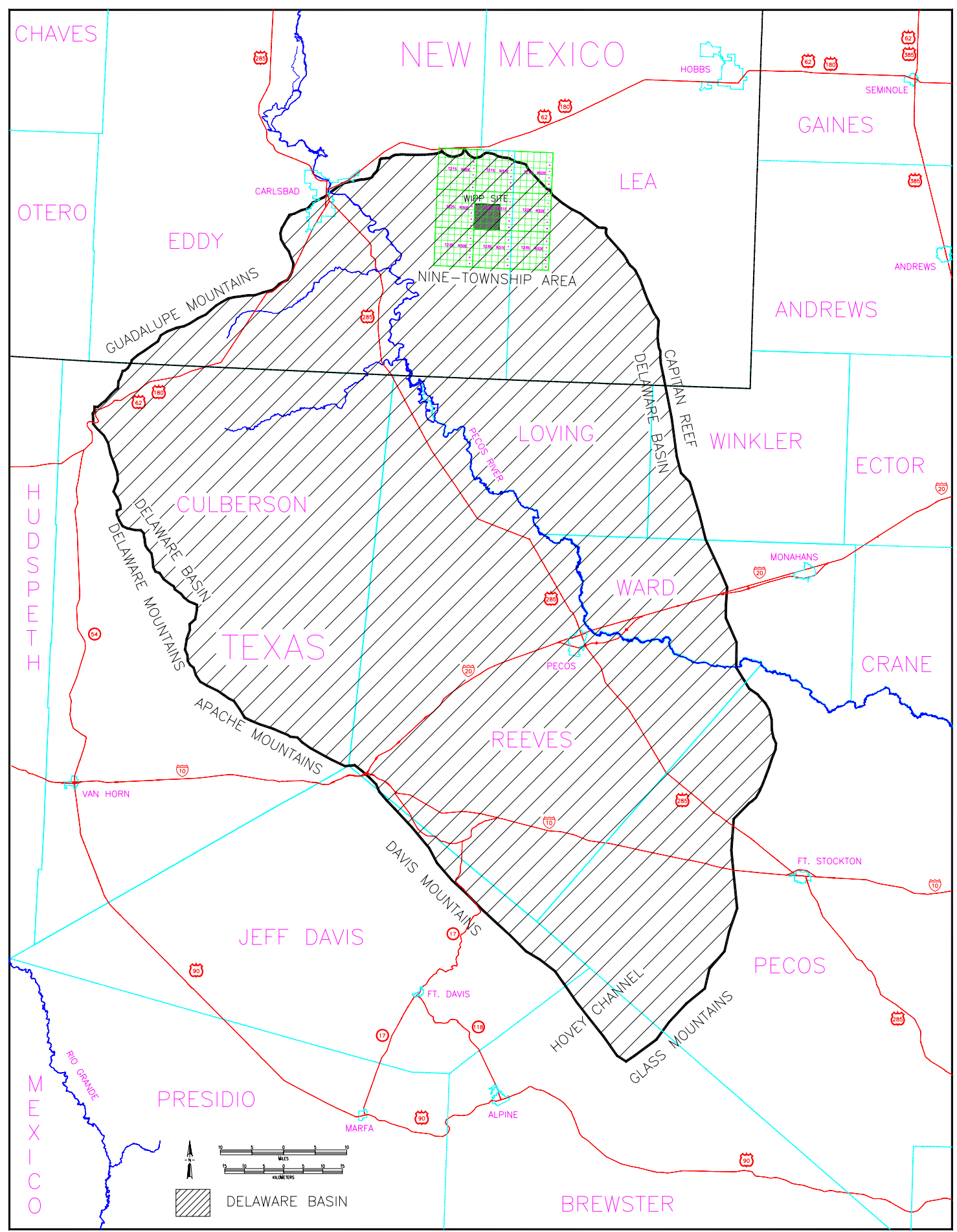

FIGURE 1

WIPP Site, Delaware Basin, and Surrounding Area 


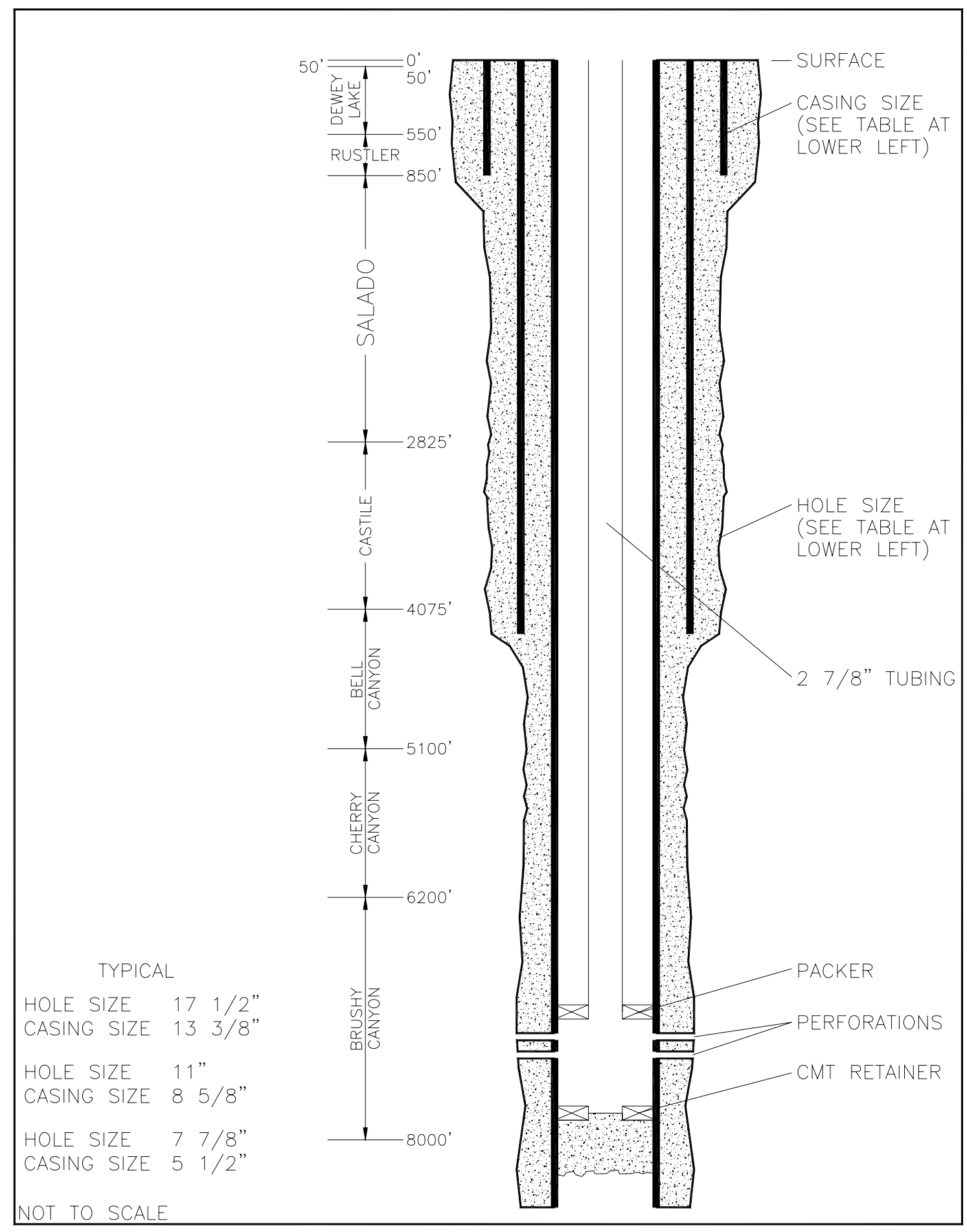

FIGURE 2

Typical Well Structure and General Stratigraphy Near the WIPP Site 


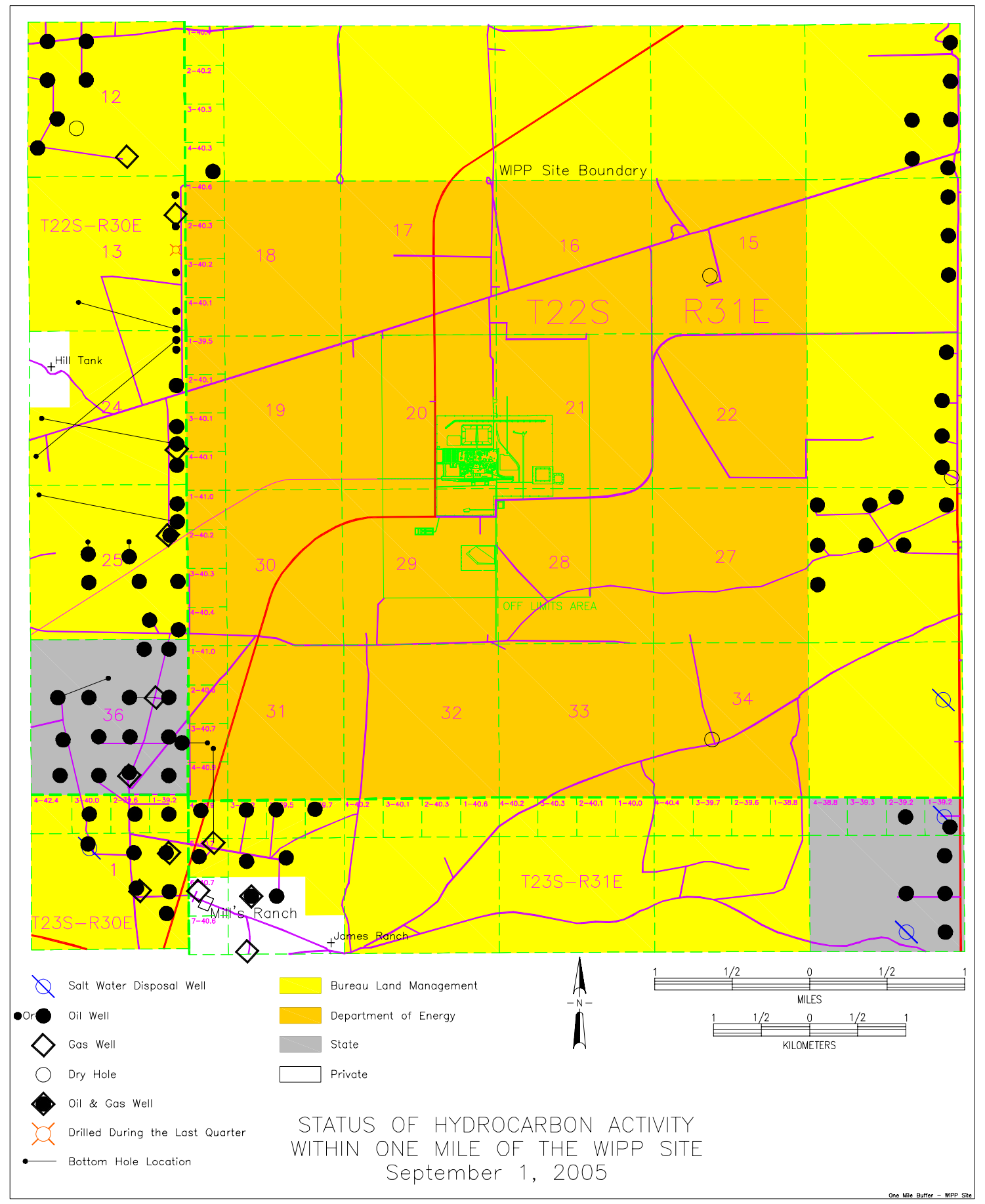

FIGURE 3

Oil and Gas Wells Within One Mile of the WIPP Site 


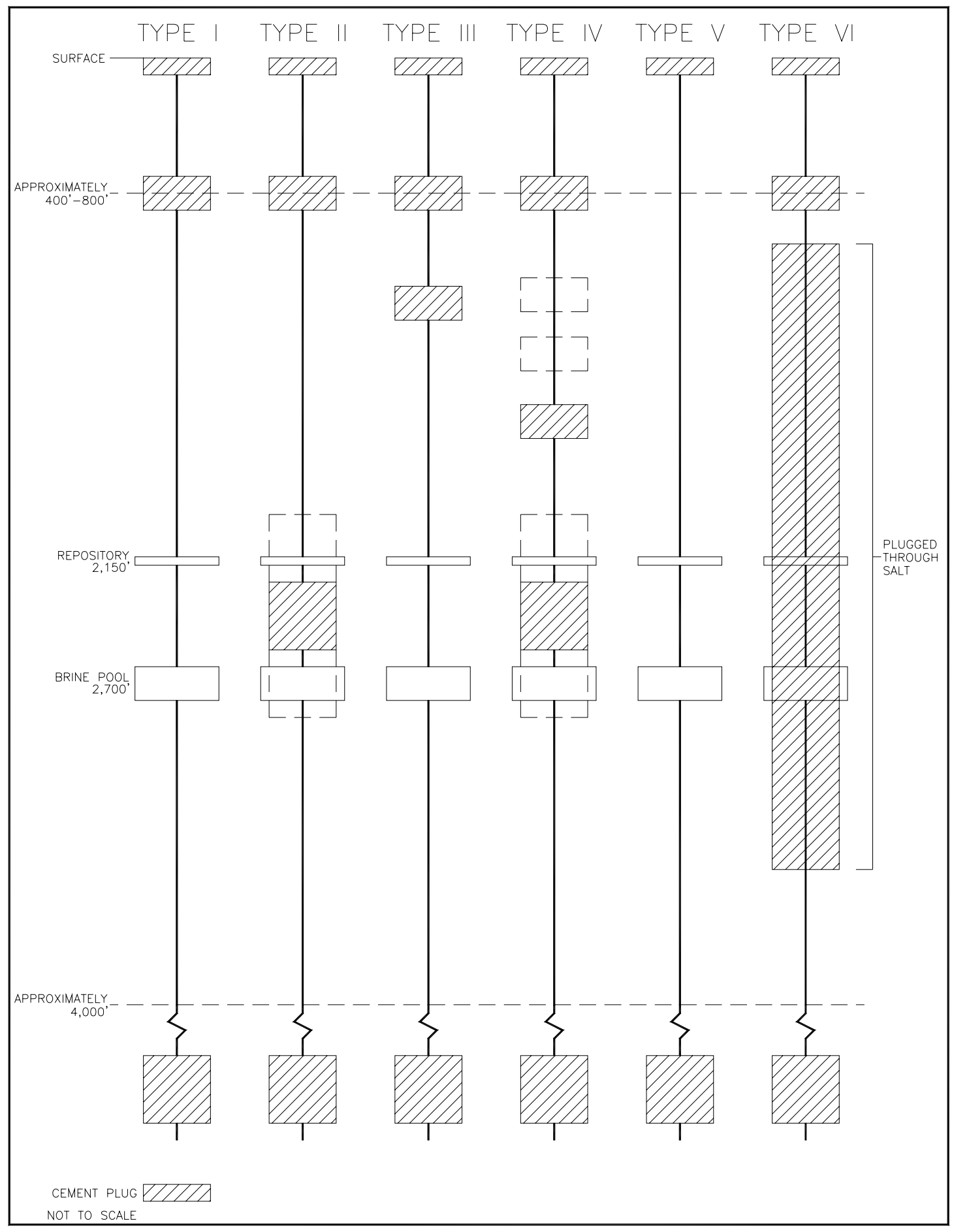

FIGURE 4

Typical Borehole Plug Configurations in the Delaware Basin 


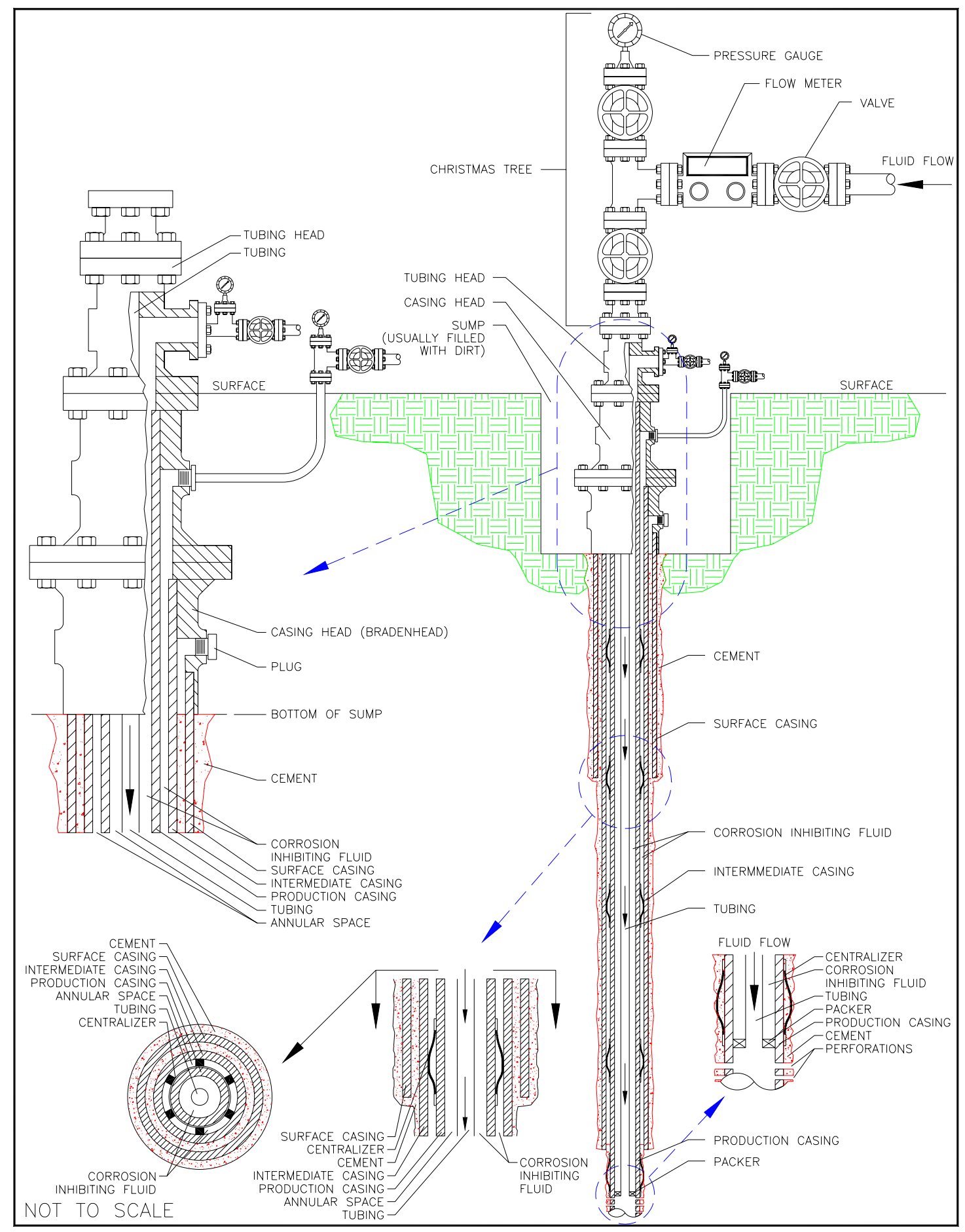

FIGURE 5

Typical Injection or Salt Water Disposal Well (SWD) 


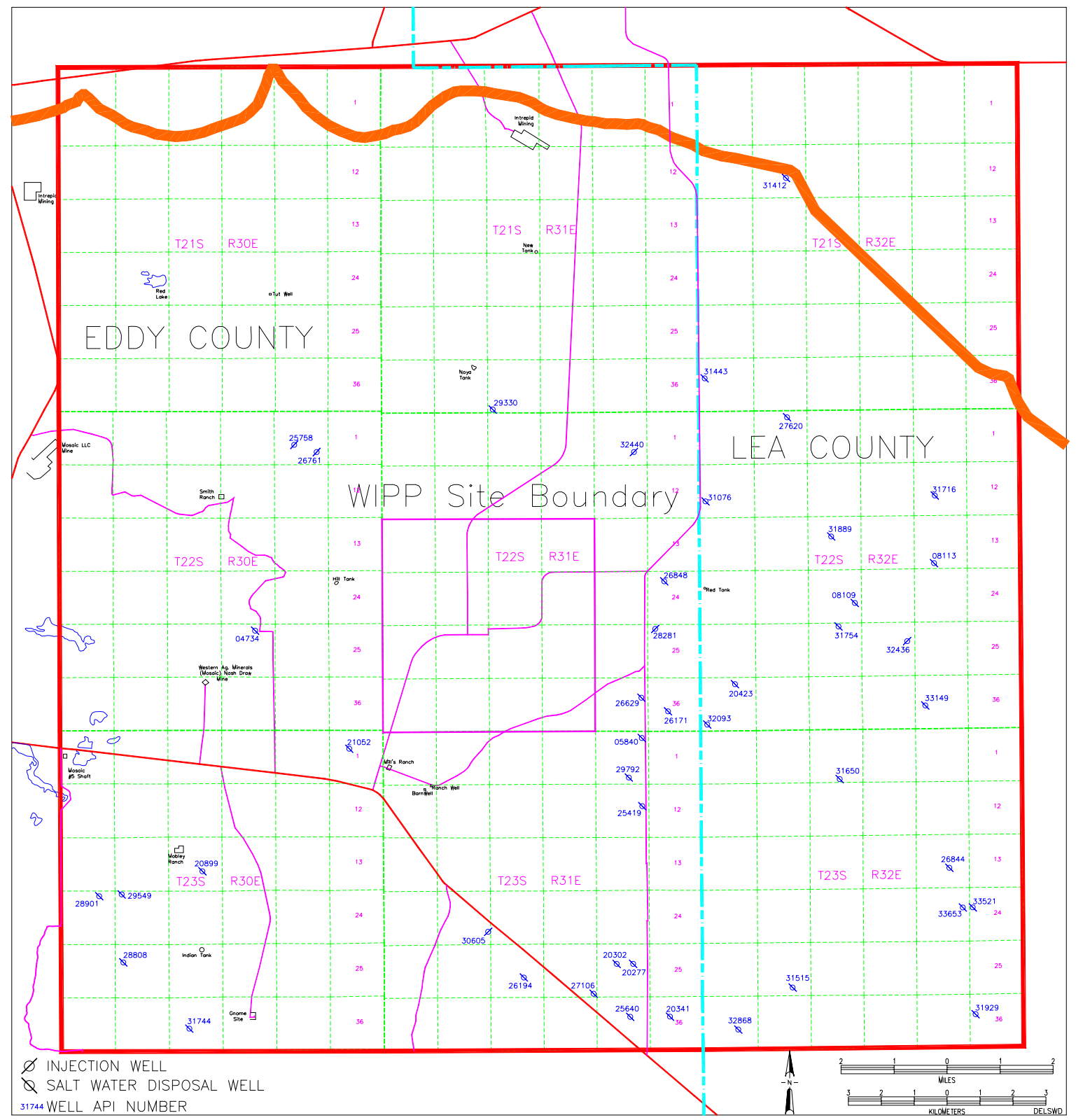

FIGURE 6

Active Injection and SWD Wells in the Nine-Township Area 


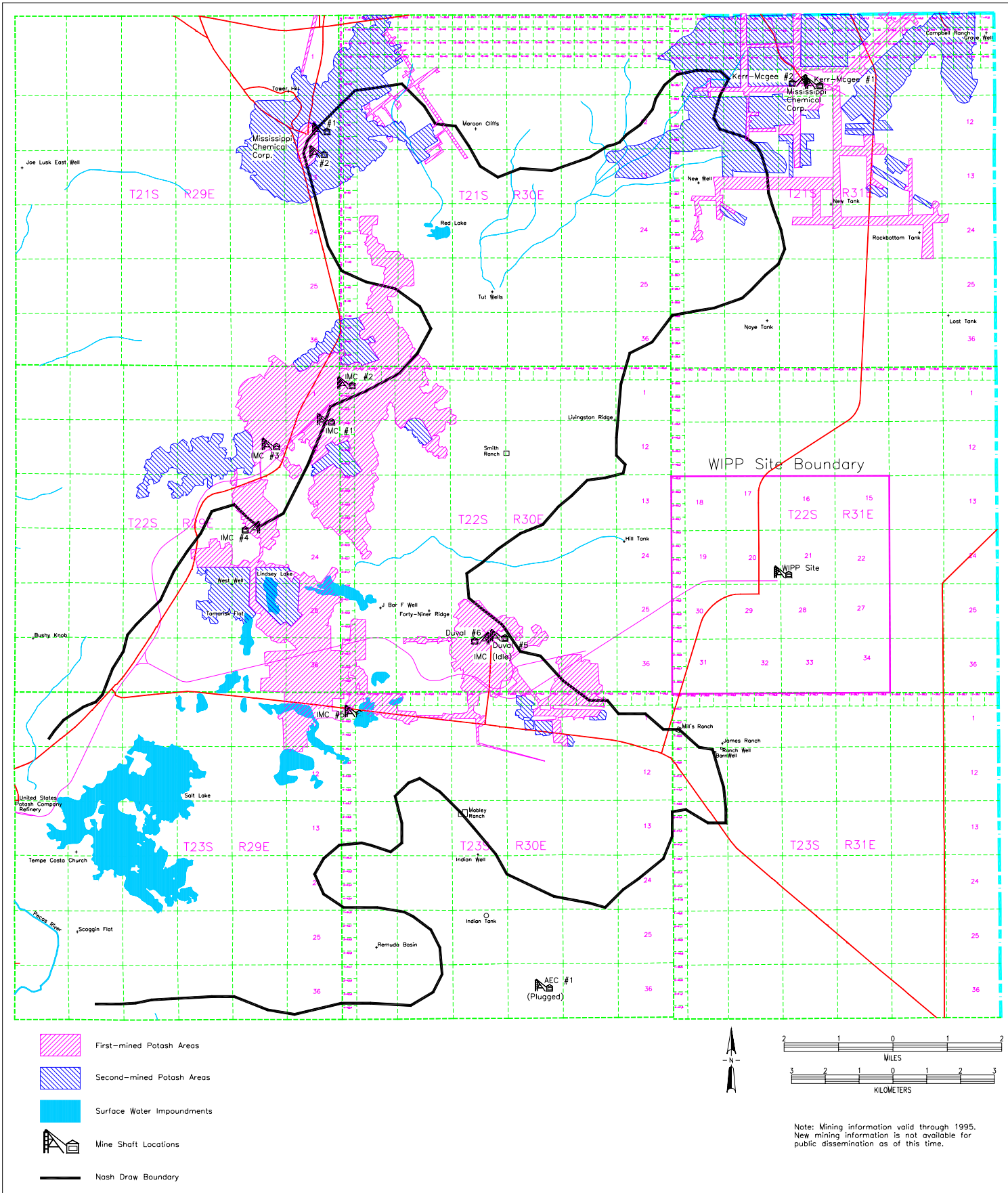

FIGURE 7

Potash Mining in the Vicinity of the WIPP Site 


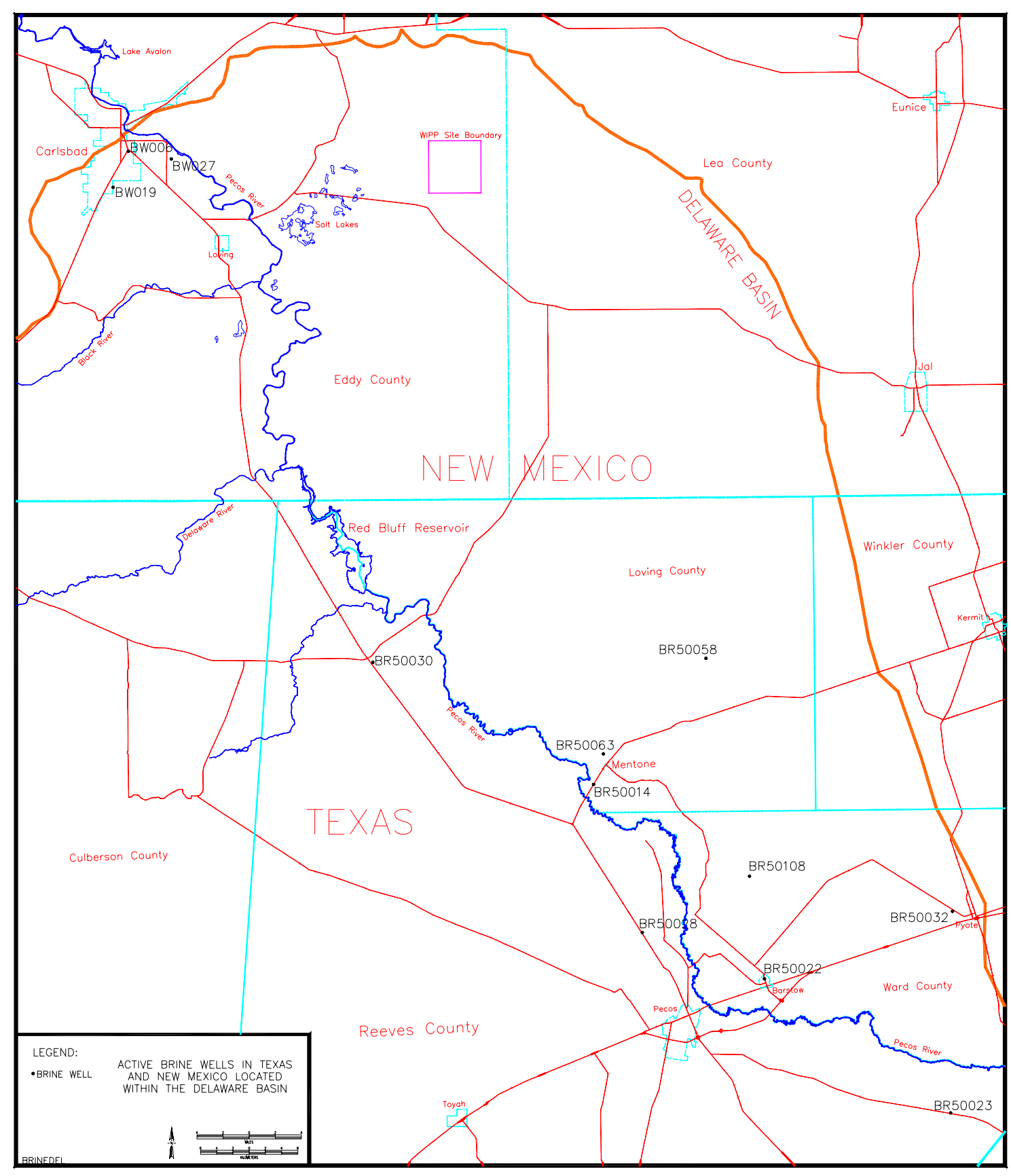

FIGURE 8

Active Brine Well Locations in the Delaware Basin 
TABLE 1

Nine-Township Area Casing Sizes

\begin{tabular}{|c|c|c|c|}
\hline Casing Size & Surface Casing & Intermediate Casing & Production Casing \\
\hline 13 3/8” & 34 & 0 & 0 \\
\hline 11 3/4” & 0 & 0 & 0 \\
\hline $95 / 8 ”$ & 0 & 3 & 0 \\
\hline 8 5/8” & 0 & 31 & 0 \\
\hline 7 " & 0 & 0 & 3 \\
\hline 5 1/2” & 0 & 0 & 31 \\
\hline
\end{tabular}

NOTE: There were 44 wells drilled in the nine-township area between September 1, 2004 and August 31, 2005. Thirty-four of the wells had complete records available on casing sizes. The other 10 wells had partial records available or had just recently been spudded.

TABLE 2

Nine-Township Area Bit Sizes

\begin{tabular}{|c|c|c|c|}
\hline Bit Size & Surface Hole & Intermediate Hole & Production Hole \\
\hline 17 1/2" & 34 & 0 & 0 \\
\hline 14 3/4” & 0 & 0 & 0 \\
\hline $121 / 4 ”$ & 0 & 3 & 0 \\
\hline $11 "$ & 0 & 31 & 0 \\
\hline 8 3/4" & 0 & 0 & 3 \\
\hline $77 / 8 "$ & 0 & 0 & 31 \\
\hline
\end{tabular}

NOTE: Of the 44 wells drilled in the nine-township area, complete records were available on 34 wells. The other 10 wells did not have records available on bit sizes. 
TABLE 3

Air-Drilled Wells in the New Mexico Portion of the Delaware Basin

\begin{tabular}{|c|c|c|c|c|c|}
\hline$\#$ & Location & Well Name and No. & Spud Date & Status & Well Information \\
\hline \multicolumn{6}{|c|}{ Wells Drilled Prior to Submittal of the 1996 CCA With Some Portion Drilled by Air. } \\
\hline 1 & 21S-28E-33 & Richardson \& Bass \#1 & 07/27/1961 & P\&A & $\begin{array}{l}\text { Air drilled through the salt. Between } \\
2,545 \text { ' and } 2,685 \text { ' encountered water and } \\
\text { changed from air to mud-based drilling. }\end{array}$ \\
\hline 2 & 21S-32E-26 & Lincoln Federal Unit \#1 & 04/01/1991 & P\&A & $\begin{array}{l}\text { Lost circulation at } 1,290 ' \text {. Hole was dry } \\
\text { drilled to } 1,792^{\prime} \text {. Supposedly, air drilled } \\
\text { from } 2,984^{\prime} \text { to } 4,725^{\prime} \text {. }\end{array}$ \\
\hline 3 & 23S-26E-17 & Exxon “17" Federal \#1 & 08/01/1989 & Gas Well & $\begin{array}{l}\text { Air drilled through the salt from } 575 \text { ' to } \\
2,707 \text { '. }\end{array}$ \\
\hline 4 & 23S-28E-11 & CP Pardue \#1 & 10/28/1958 & P\&A & $\begin{array}{l}\text { Air drilled through the salt from } 390 \text { ' to } \\
2,620^{\prime} \text {. }\end{array}$ \\
\hline 5 & 23S-28E-11 & Amoco Federal \#1 & 08/04/1979 & Oil Well & Air drilled from $475^{\prime}$ to $9,700^{\prime}$. \\
\hline 6 & 23S-28E-11 & Amoco Federal \#3 & 02/28/1980 & Oil Well & Air drilled from 6,271' to 9,692 '. \\
\hline 7 & 23S-28E-23 & South Culebra Bluff Unit \#3 & 01/21/1979 & Oil Well & Air drilled from $6,345^{\prime}$ to 8,000 '. \\
\hline 8 & 23S-28E-23 & South Culebra Bluff Unit \#4 & 08/09/1979 & Oil Well & Air drilled from 450 ' to $9,802^{\prime}$. \\
\hline 9 & 24S-31E-03 & Lilly “ALY” Federal \#2 & 05/01/1994 & Oil Well & Air drilled conductor hole to $40^{\prime}$. \\
\hline 10 & 24S-31E-03 & Lilly “ALY” Federal \#4 & 05/16/1994 & Oil Well & Air drilled conductor hole to $40^{\prime}$. \\
\hline 11 & 24S-34E-04 & Antelope Ridge Unit \#2 & 09/13/1962 & Gas Well & $\begin{array}{l}\text { Attempted to drill with gas. Had to } \\
\text { convert to water at } 1,035 \text { '. Tried again } \\
\text { several times at different depths. }\end{array}$ \\
\hline 12 & 24S-34E-09 & Federal “9" Com \#1 & $12 / 03 / 1963$ & Gas Well & Hit water while gas drilling at $4,865 '$. \\
\hline 13 & 24S-34E-13 & Federal Johnson \#1 & 06/23/1958 & P\&A & $\begin{array}{l}\text { Proposed to drill with air, but no } \\
\text { information in the records indicate air } \\
\text { drilling. }\end{array}$ \\
\hline 14 & 26S-32E-20 & Russell Federal \#1 & 03/16/1966 & Oil Well & Drilled with air to 1,330 '. \\
\hline 15 & 26S-32E-36 & North El Mar Unit \#44 & 02/19/1959 & Oil Well & $\begin{array}{l}\text { Proposed to drill with air, but no } \\
\text { information in the records indicate air } \\
\text { drilling. }\end{array}$ \\
\hline \multicolumn{6}{|c|}{ Wells Drilled after Supplemental Information Provided to the EPA Docket in 1997.} \\
\hline 16 & 22S-26E-28 & Sheep Draw “28" Federal \#13 & 07/01/1997 & Oil Well & Air drilled the first 358'. \\
\hline
\end{tabular}

NOTE: The research on "air drilling” is a continuous effort since every new well drilled is checked to determine if any portion of the well was drilled by air. A copy of all completion reports are on file for all wells completed within the New Mexico portion of the Delaware Basin. 


\section{TABLE 4}

Shallow Well Status in the Delaware Basin

\begin{tabular}{|c|c|c|c|}
\hline Well Type & Texas & New Mexico & Totals \\
\hline Core Hole & 31 & 2 & 33 \\
\hline Dry Hole & 325 & 146 & 471 \\
\hline Gas Well & 8 & 3 & 11 \\
\hline Injection Well & 5 & 0 & 5 \\
\hline Junked and Abandoned Well & 61 & 29 & 90 \\
\hline Oil Well & 88 & 7 & 95 \\
\hline Oil and Gas Well & 1 & 0 & 1 \\
\hline Plugged Gas Well & 1 & 2 & 3 \\
\hline Plugged Oil Well & 14 & 14 & 28 \\
\hline Plugged Brine Well & 2 & 1 & 3 \\
\hline Plugged Salt Water Disposal Well & 0 & 4 & 4 \\
\hline Drilling or Waiting on Paperwork & 147 & 83 & 230 \\
\hline Brine Well & 1 & 4 & 5 \\
\hline Salt Water Disposal Well & 0 & 1 & 1 \\
\hline Service Well & 13 & 0 & 13 \\
\hline Stratigraphic Test Hole & 1,170 & 0 & 1,170 \\
\hline Sulfur Core Hole & 502 & 0 & 502 \\
\hline Potash Core Hole & 0 & 992 & 992 \\
\hline Water Well & 1,706 & 590 & 2,296 \\
\hline WIPP Well & 0 & 192 & 192 \\
\hline Other (Mine Shafts, Gnome Project Wells) & 0 & 44 & 44 \\
\hline TOTALS & 4,075 & 2,114 & 6,189 \\
\hline
\end{tabular}

NOTE: Only the known holes that occur in the Delaware Basin, except several WIPP holes, are listed in the above table. The WIPP holes are shown for completeness. The 230 wells under the listing of "Drilling or Waiting on Paperwork" do not have an associated depth until one has been reported on paperwork. These are listed as shallow wells but may eventually be placed in the deep classification when a depth has been listed in the paperwork. 
TABLE 5

Deep Well Status in the Delaware Basin

\begin{tabular}{|c|c|c|c|}
\hline Well Type & Texas & New Mexico & Totals \\
\hline Core Hole & 5 & 0 & 5 \\
\hline Dry Hole & 2,185 & 841 & 3,026 \\
\hline Gas Well & 904 & 737 & 1,641 \\
\hline Injection Well & 241 & 66 & 307 \\
\hline Junked and Abandoned Well & 58 & 18 & 76 \\
\hline Oil Well & 3,811 & 2,062 & 5,873 \\
\hline Oil and Gas Well & 86 & 5 & 91 \\
\hline Plugged Gas Well & 187 & 149 & 336 \\
\hline Plugged Injection Well & 37 & 30 & 67 \\
\hline Plugged Oil Well & 608 & 330 & 938 \\
\hline Plugged Oil and Gas Well & 35 & 0 & 35 \\
\hline Plugged Brine Well & 0 & 1 & 1 \\
\hline Plugged Salt Water Disposal Well & 3 & 12 & 15 \\
\hline Plugged Service Well & 2 & 0 & 2 \\
\hline Drilling or Waiting on Paperwork & 14 & 1 & 15 \\
\hline Brine Well & 8 & 0 & 8 \\
\hline Salt Water Disposal Well & 7 & 110 & 117 \\
\hline Service Well & 97 & 2 & 99 \\
\hline Stratigraphic Test Hole & 44 & 2 & 46 \\
\hline Sulfur Core Hole & 85 & 0 & 85 \\
\hline Potash Core Hole & 0 & 19 & 19 \\
\hline WIPP Well & 0 & 11 & 11 \\
\hline Other (Mine Shafts, Gnome Project Wells) & 0 & 6 & 6 \\
\hline TOTALS & 8,417 & 4,402 & 12,819 \\
\hline
\end{tabular}

NOTE: The 15 wells under the category of "Drilling or Waiting on Paperwork" have a depth associated with them which classifies them as deep wells, but the paperwork classifying these wells as oil, gas, or some other type of well have yet to be posted. When posted, the classification of these types of wells will be changed. 
TABLE 6

Past Drilling Rates for the Delaware Basin

\begin{tabular}{|c|c|c|}
\hline Year & No. of Deep Holes & Drilling Rate \\
\hline 1996 & 10,804 Holes Deeper Than 2,150 Ft & 46.8 \\
\hline 1997 & 11,444 Holes Deeper Than 2,150 Ft & 49.5 \\
\hline 1998 & 11,616 Holes Deeper Than 2,150 Ft & 50.3 \\
\hline 1999 & 11,684 Holes Deeper Than 2,150 Ft & 50.6 \\
\hline 2000 & 11,828 Holes Deeper Than 2,150 Ft & 51.2 \\
\hline 2001 & 12,056 Holes Deeper Than 2,150 Ft & 52.2 \\
\hline $2002^{1}$ & 12,139 Holes Deeper Than 2,150 Ft & 52.5 \\
\hline 2003 & 12,316 Holes Deeper Than 2,150 Ft & 53.3 \\
\hline 2004 & 12,531 Holes Deeper Than 2,150 Ft & 54.2 \\
\hline
\end{tabular}

Note: The notable increase in the drilling rate between 1996 and 1997 was not due to the drilling of wells, but to the fact that the Delaware Basin Drilling Surveillance Program was not began until 1997 when a review of the records from July 1995 through 1997 was necessary to bring the databases up to date. Since that time, the drilling rate has risen approximately the same each year.

In Rev. 3 of this report dated September 2002, the drilling rate for 2002 was shown as 52.9 with 12,219 deep holes. While reviewing the databases to develop reports for the Compliance Recertification Application, it was noticed that 80 shallow wells in Texas were listed as being deep. Several days investigation found the problem, and it was corrected. Correcting the classification of the 80 holes to shallow resulted in a reduction in the drilling rate from 52.9 to 52.5. This was reported in December 2002. 
TABLE 7

Castile Brine Encounters in the Vicinity of the WIPP Site

\begin{tabular}{|c|c|c|c|c|c|}
\hline \# & Location & Well Name and No. & Spud Date & Status & Well Information \\
\hline \multicolumn{6}{|c|}{ Original CCA-related Castile Brine Encounters - 1896 Through June 1995} \\
\hline 1 & 21S-31E-26 & Federal \#1 & $10 / 31 / 1979$ & P\&A & Identified as encountering Castile Brine. \\
\hline 2 & 21S-31E-35 & ERDA-6 & 06/13/1975 & P\&A & Identified as encountering Castile Brine. \\
\hline 3 & 21S-31E-35 & Federal “FI" \#1 & 09/25/1981 & $\mathrm{P} \& \mathrm{~A}$ & Identified as encountering Castile Brine. \\
\hline 4 & 21S-31E-36 & Lost Tank “AIS” State \#1 & $12 / 07 / 1991$ & Oil Well & Identified as encountering Castile Brine. \\
\hline 5 & 21S-31E-36 & Lost Tank “AIS” State \#4 & $11 / 19 / 1991$ & Oil Well & Identified as encountering Castile Brine. \\
\hline 6 & 21S-32E-31 & Lost Tank SWD \#1 & $11 / 12 / 1991$ & SWD & Identified as encountering Castile Brine. \\
\hline 7 & 22S-29E-09 & Danford Permit \#1 & 05/18/1937 & P\&A & Identified as encountering Castile Brine. \\
\hline 8 & 22S-31E-01 & Unocal “AHU” Federal \#1 & 04/02/1991 & Oil Well & Identified as encountering Castile Brine. \\
\hline 9 & 22S-31E-01 & Molly State \#1 & 09/25/1991 & Oil Well & Identified as encountering Castile Brine. \\
\hline 10 & 22S-31E-01 & Molly State \#3 & 10/20/1991 & Oil Well & Identified as encountering Castile Brine. \\
\hline 11 & 22S-31E-02 & State "2" \#3 & $11 / 28 / 1991$ & Oil Well & Identified as encountering Castile Brine. \\
\hline 12 & 22S-31E-11 & Martha “AIK” Federal \#3 & 05/06/1991 & Oil Well & Identified as encountering Castile Brine. \\
\hline 13 & 22S-31E-11 & Martha “AIK” Federal \#4 & 09/02/1991 & Oil Well & Identified as encountering Castile Brine. \\
\hline 14 & 22S-31E-12 & Federal “12" \#8 & 03/28/1992 & Oil Well & Identified as encountering Castile Brine. \\
\hline 15 & 22S-31E-13 & Neff “13" Federal \#5 & 02/04/1991 & Oil Well & Identified as encountering Castile Brine. \\
\hline 16 & 22S-31E-17 & WIPP-12 & $11 / 17 / 1978$ & Monitoring & Identified as encountering Castile Brine. \\
\hline 17 & 22S-32E-05 & Bilbrey “5" Federal \#1 & $11 / 26 / 1981$ & Oil Well & Identified as encountering Castile Brine. \\
\hline 18 & 22S-32E-15 & Lechuza Federal \#4 & 12/29/1992 & Oil Well & Identified as encountering Castile Brine. \\
\hline 19 & 22S-32E-16 & Kiwi “AKX” State \#1 & 04/28/1992 & Oil Well & Identified as encountering Castile Brine. \\
\hline 20 & 22S-32E-25 & Covington “A” Federal \#1 & 02/07/1975 & Oil Well & Identified as encountering Castile Brine. \\
\hline 21 & 22S-32E-26 & Culberson \#1 & $12 / 15 / 1944$ & P\&A & Identified as encountering Castile Brine. \\
\hline 22 & 22S-32E-34 & Red Tank “34" Federal \#1 & 09/23/1992 & Oil Well & Identified as encountering Castile Brine. \\
\hline 23 & 22S-32E-36 & Richardson State \#1 & 07/20/1962 & P\&A & Identified as encountering Castile Brine. \\
\hline 24 & 22S-32E-36 & Shell State \#1 & $02 / 22 / 1964$ & Oil Well & Identified as encountering Castile Brine. \\
\hline 25 & 22S-33E-20 & Cloyd Permit \#1 & 09/07/1937 & P\&A & Identified as encountering Castile Brine. \\
\hline 26 & 22S-33E-20 & Cloyd Permit \#2 & 06/22/1938 & P\&A & Identified as encountering Castile Brine. \\
\hline 27 & 23S-30E-01 & Hudson Federal \#1 & 02/25/1974 & SWD & Identified as encountering Castile Brine. \\
\hline \multicolumn{6}{|c|}{ Castile Brine Encounters Since July 1995} \\
\hline 1 & 21S-31E-35 & Lost Tank “35" State \#4 & 09/11/2000 & Oil Well & Estimated several hundred barrels per hour. Continued drilling. \\
\hline
\end{tabular}




\begin{tabular}{|c|c|c|c|c|c|}
\hline \# & Location & Well Name and No. & Spud Date & Status & Well Information \\
\hline 2 & 21S-31E-35 & Lost Tank “35" State \#16 & 02/06/2002 & Oil Well & $\begin{array}{l}\text { At } 2,705 \mathrm{ft} \text {., encountered } 1,000 \text { barrels per hour. Shut-in to get } \\
\text { room in reserve pit with pressure of } 180 \mathrm{psi} \text {. Shut-in next day } \\
\text { with pressure at } 100 \mathrm{psi} \text { and waterflow of } 450 \mathrm{~B} / \mathrm{H} \text {. Two days } \\
\text { later no water flow and full returns. }\end{array}$ \\
\hline 3 & 22S-31E-02 & Graham “AKB”State \#8 & $04 / 12 / 2002$ & Oil Well & Estimated 105 barrels per hour. Continued drilling. \\
\hline 4 & 23S-30E-01 & James Ranch Unit \#63 & $12 / 23 / 1999$ & Oil Well & $\begin{array}{l}\text { Sulfur water encountered at } 2,900 \mathrm{ft} \text {. } 35 \mathrm{ppm} \text { was reported but } \\
\text { quickly dissipated to } 3 \mathrm{ppm} \text { in a matter of minutes. Continued } \\
\text { drilling. }\end{array}$ \\
\hline 5 & 23S-30E-01 & Hudson “1" Federal \#7 & 01/06/2001 & Oil Well & $\begin{array}{l}\text { Estimated initial flow at } 400 \text { to } 500 \text { barrels per hour with a total } \\
\text { volume of } 600 \text { to } 800 \text { barrels. Continued drilling. }\end{array}$ \\
\hline 6 & $22 \mathrm{~S}-30 \mathrm{E}-13$ & Apache “13" Federal \#3 & $11 / 26 / 2003$ & Oil Well & $\begin{array}{l}\text { Encountered strong water flow with blowing air at 2,850-3,315 } \\
\text { ft. No impact on drilling process. }\end{array}$ \\
\hline 7 & 21S-31E-34 & Jacque “AQJ” State \#7 & 03/04/2005 & Oil Well & $\begin{array}{l}\text { Encountered water flow of } 104 \text { barrels per hour at } 2,900 \mathrm{ft} \text {. No } \\
\text { impact on drilling process. }\end{array}$ \\
\hline
\end{tabular}


TABLE 8

Plugged Well Information

\begin{tabular}{|c|c|c|c|c|c|c|c|}
\hline$\#$ & Location & API \# & Plug Date & $R-111-P$ & Well Depth & Plug Depth & Plug Length \\
\hline 1 & 21S-29E-05 & 30-015-23735 & $11 / 24 / 2004$ & No & $12,796 \mathrm{Ft}$ & $\begin{array}{c}11,570 \\
7,800 \\
6,500 \\
4,400 \\
2,000 \\
600 \\
\text { Surface }\end{array}$ & $\begin{array}{l}\text { Unknown } \\
\text { Unknown } \\
\text { Unknown } \\
\text { Unknown } \\
\text { Unknown } \\
\text { Unknown } \\
\text { Unknown }\end{array}$ \\
\hline 2 & 21S-32E-30 & $30-025-33647$ & 04/20/2005 & Yes & $8,916 \mathrm{Ft}$ & $\begin{array}{c}6,700 \\
4,550-4,300 \\
855-755 \\
100-0\end{array}$ & $\begin{array}{l}\text { Unknown } \\
250 \mathrm{Ft} \\
100 \mathrm{Ft} \\
100 \mathrm{Ft}\end{array}$ \\
\hline 3 & $22 S-26 E-28$ & $30-015-27488$ & $11 / 04 / 2004$ & No & $5,002 \mathrm{Ft}$ & $\begin{array}{c}4,200-4,165 \\
3,250-3,215 \\
1,700-1,450 \\
425-0\end{array}$ & $\begin{array}{c}35 \mathrm{Ft} \\
35 \mathrm{Ft} \\
250 \mathrm{Ft} \\
425 \mathrm{Ft}\end{array}$ \\
\hline 4 & $22 \mathrm{~S}-32 \mathrm{E}-17$ & $30-025-24823$ & 05/24/2005 & No & $14,800 \mathrm{Ft}$ & $\begin{array}{c}8,350 \\
6,780 \\
4,850 \\
4,750-4,608 \\
1,750-1,605 \\
568-380 \\
60-0\end{array}$ & $\begin{array}{c}\text { Unknown } \\
\text { Unknown } \\
\text { Unknown } \\
142 \mathrm{Ft} \\
145 \mathrm{Ft} \\
188 \mathrm{Ft} \\
60 \mathrm{Ft}\end{array}$ \\
\hline 5 & 22S-32E-18 & $30-025-32149$ & 03/16/2005 & No & $8,782 \mathrm{Ft}$ & $\begin{array}{c}6,770-6,760 \\
4,524-4,424 \\
1,316-1,117 \\
759 \\
\text { Surface }\end{array}$ & $\begin{array}{c}10 \mathrm{Ft} \\
100 \mathrm{Ft} \\
199 \mathrm{Ft} \\
\text { Unknown } \\
\text { Unknown }\end{array}$ \\
\hline 6 & $22 \mathrm{~S}-32 \mathrm{E}-23$ & $30-025-32376$ & 01/09/2005 & No & $10,110 \mathrm{Ft}$ & $\begin{array}{c}8,375-8,113 \\
5,113-4,493 \\
3,068-2,812 \\
1,200-757 \\
300-0\end{array}$ & $\begin{array}{l}262 \mathrm{Ft} \\
620 \mathrm{Ft} \\
256 \mathrm{Ft} \\
443 \mathrm{Ft} \\
300 \mathrm{Ft}\end{array}$ \\
\hline 7 & $22 S-32 E-23$ & $30-025-32627$ & 02/09/2005 & No & $10,081 \mathrm{Ft}$ & $\begin{array}{c}8,200-7,890 \\
4,900-4,390 \\
2,750-2,523 \\
1,150-796 \\
300-0\end{array}$ & $\begin{array}{l}310 \mathrm{Ft} \\
510 \mathrm{Ft} \\
227 \mathrm{Ft} \\
354 \mathrm{Ft} \\
300 \mathrm{Ft}\end{array}$ \\
\hline 8 & 22S-32E-23 & 30-025-32885 & 01/05/2005 & No & $5,090 \mathrm{Ft}$ & $\begin{array}{c}4,900-4,647 \\
4,500-4,247 \\
1,300-793 \\
300-0\end{array}$ & $\begin{array}{l}253 \mathrm{Ft} \\
253 \mathrm{Ft} \\
507 \mathrm{Ft} \\
300 \mathrm{Ft}\end{array}$ \\
\hline 9 & 23S-26E-04 & $30-015-29471$ & 01/06/2005 & No & $11,858 \mathrm{Ft}$ & $\begin{array}{c}10,180-10,145 \\
9,221-8,882 \\
6,500-6,341 \\
4,045-3,886 \\
1,545-1,386 \\
600-441 \\
60-0\end{array}$ & $\begin{array}{l}35 \mathrm{Ft} \\
339 \mathrm{Ft} \\
159 \mathrm{Ft} \\
159 \mathrm{Ft} \\
159 \mathrm{Ft} \\
159 \mathrm{Ft} \\
60 \mathrm{Ft}\end{array}$ \\
\hline
\end{tabular}




\begin{tabular}{|c|c|c|c|c|c|c|c|}
\hline$\#$ & Location & API \# & Plug Date & $R-111-P$ & Well Depth & Plug Depth & Plug Length \\
\hline 10 & 23S-26E-24 & 30-015-21051 & 05/18/2005 & No & $12,005 \mathrm{Ft}$ & $\begin{array}{c}8,712-8,540 \\
5,311-4,898 \\
1,970-1,860 \\
840-660 \\
420-290 \\
60-0\end{array}$ & $\begin{array}{l}172 \mathrm{Ft} \\
413 \mathrm{Ft} \\
110 \mathrm{Ft} \\
180 \mathrm{Ft} \\
130 \mathrm{Ft} \\
60 \mathrm{Ft}\end{array}$ \\
\hline 11 & 23S-31E-12 & 30-015-29785 & 04/21/2005 & Yes & $8,510 \mathrm{Ft}$ & $\begin{array}{c}8,100-7,380 \\
6,835-6,582 \\
5,590-5,410 \\
4,400-4,200 \\
4,000-3,888 \\
2,650-2,500 \\
930-780 \\
60-0\end{array}$ & $\begin{array}{l}720 \mathrm{Ft} \\
253 \mathrm{Ft} \\
180 \mathrm{Ft} \\
200 \mathrm{Ft} \\
112 \mathrm{Ft} \\
150 \mathrm{Ft} \\
150 \mathrm{Ft} \\
60 \mathrm{Ft}\end{array}$ \\
\hline 12 & 23S-32E-18 & $30-025-25622$ & 02/14/2005 & No & $9,300 \mathrm{Ft}$ & $\begin{array}{c}8,325-8,290 \\
6,849-6,649 \\
4,700-4,500 \\
2,600-2,400 \\
1,016-830 \\
60-0\end{array}$ & $\begin{array}{l}35 \mathrm{Ft} \\
200 \mathrm{Ft} \\
200 \mathrm{Ft} \\
200 \mathrm{Ft} \\
186 \mathrm{Ft} \\
60 \mathrm{Ft}\end{array}$ \\
\hline 13 & 23S-32E-34 & 30-025-33351 & $10 / 11 / 2004$ & No & $10,199 \mathrm{Ft}$ & $\begin{array}{c}7,400-7,200 \\
6,100-5,900 \\
5,000-4,574 \\
2,550-2,371 \\
700-0\end{array}$ & $\begin{array}{l}200 \mathrm{Ft} \\
200 \mathrm{Ft} \\
426 \mathrm{Ft} \\
179 \mathrm{Ft} \\
700 \mathrm{Ft}\end{array}$ \\
\hline 14 & 24S-28E-01 & $30-015-26249$ & 05/23/2005 & No & $12,186 \mathrm{Ft}$ & $\begin{array}{c}9,865 \\
8,002 \\
6,420-6,270 \\
5,056-4,888 \\
2,765-2,517 \\
556-406 \\
60-0\end{array}$ & $\begin{array}{c}\text { Unknown } \\
\text { Unknown } \\
150 \mathrm{Ft} \\
168 \mathrm{Ft} \\
248 \mathrm{Ft} \\
150 \mathrm{Ft} \\
60 \mathrm{Ft}\end{array}$ \\
\hline 15 & 25S-25E-10 & $30-015-28608$ & 09/26/2004 & No & $5,170 \mathrm{Ft}$ & $\begin{array}{c}4,479-4,502 \\
1,490-1,243 \\
280-0\end{array}$ & $\begin{array}{l}247 \mathrm{Ft} \\
247 \mathrm{Ft} \\
280 \mathrm{Ft}\end{array}$ \\
\hline 16 & $25 S-26 E-26$ & $30-015-28532$ & 02/21/2005 & No & $5,613 \mathrm{Ft}$ & $\begin{array}{c}2,900-2,700 \\
1,900-1,500 \\
1,000-900 \\
340-0\end{array}$ & $\begin{array}{l}200 \mathrm{Ft} \\
400 \mathrm{Ft} \\
100 \mathrm{Ft} \\
340 \mathrm{Ft}\end{array}$ \\
\hline 17 & 25S-32E-07 & $30-025-35086$ & 05/13/2005 & No & $13,115 \mathrm{Ft}$ & $\begin{array}{c}12,535-12,385 \\
10,750-10,600 \\
8,750-8,600 \\
6,750-6,600 \\
4,450-4,255 \\
2,002-1,850 \\
782-627 \\
62-0 \\
\end{array}$ & $\begin{array}{l}150 \mathrm{Ft} \\
150 \mathrm{Ft} \\
150 \mathrm{Ft} \\
150 \mathrm{Ft} \\
195 \mathrm{Ft} \\
152 \mathrm{Ft} \\
155 \mathrm{Ft} \\
62 \mathrm{Ft}\end{array}$ \\
\hline 18 & 26S-29E-13 & $30-015-25144$ & $10 / 14 / 2004$ & No & $6,450 \mathrm{Ft}$ & $\begin{array}{c}5,200 \\
4,607-4,363 \\
3,222-2,826 \\
2,243-2,092 \\
1,060-948 \\
418-0\end{array}$ & $\begin{array}{c}\text { Unknown } \\
244 \mathrm{Ft} \\
396 \mathrm{Ft} \\
151 \mathrm{Ft} \\
112 \mathrm{Ft} \\
418 \mathrm{Ft}\end{array}$ \\
\hline
\end{tabular}




\begin{tabular}{|c|c|c|c|c|c|c|c|}
\hline \# & Location & API \# & Plug Date & $R-111-P$ & Well Depth & Plug Depth & Plug Length \\
\hline 19 & 26S-33E-15 & 30-025-08415 & 09/10/2004 & No & $5,300 \mathrm{Ft}$ & $\begin{array}{c}4,905-4,870 \\
4,765 \\
2,000-1,748 \\
457-297 \\
60-0\end{array}$ & $\begin{array}{c}35 \mathrm{Ft} \\
\text { Unknown } \\
252 \mathrm{Ft} \\
160 \mathrm{Ft} \\
60 \mathrm{Ft}\end{array}$ \\
\hline 20 & 25S-34E-27 & $30-025-36929$ & $12 / 23 / 2004$ & No & $12,600 \mathrm{Ft}$ & $\begin{array}{c}12,600-12,350 \\
9,250-9,050 \\
7,000-6,800 \\
5,285-5,067 \\
2,500-2,400 \\
100-0\end{array}$ & $\begin{array}{l}250 \mathrm{Ft} \\
200 \mathrm{Ft} \\
200 \mathrm{Ft} \\
218 \mathrm{Ft} \\
200 \mathrm{Ft} \\
100 \mathrm{Ft}\end{array}$ \\
\hline
\end{tabular}


TABLE 9

Plugging Summary by Well Type

\begin{tabular}{|c|r|c|r|r|r|r|r|r|r|c|}
\hline Type & CRA & $\begin{array}{c}\text { CRA } \\
\text { Frequency }\end{array}$ & 2003 & 2004 & 2005 & 2006 & 2007 & Total & $\begin{array}{c}\text { Current } \\
\text { Frequency }\end{array}$ & Change \\
\hline I & 116 & $34.1 \%$ & 3 & 4 & 5 & & & 128 & $31.6 \%$ & $-2.5 \%$ \\
\hline II & 60 & $17.7 \%$ & 2 & 5 & 9 & & & 76 & $18.8 \%$ & $+1.1 \%$ \\
\hline III & 111 & $32.6 \%$ & 10 & 8 & 6 & & & 135 & $33.3 \%$ & $+0.7 \%$ \\
\hline IV & 38 & $11.2 \%$ & 3 & 5 & 0 & & & 46 & $11.4 \%$ & $+0.2 \%$ \\
\hline V & 10 & $02.9 \%$ & 1 & 1 & 0 & & & 12 & $03.0 \%$ & $+0.1 \%$ \\
\hline VI & 5 & $01.5 \%$ & 1 & 2 & 0 & & & 8 & $01.9 \%$ & $+0.4 \%$ \\
\hline TOTALS & 340 & $100.0 \%$ & 20 & 25 & 20 & & & 405 & $100.0 \%$ & \\
\hline
\end{tabular}

NOTE: The 1996 CCA used the 188 wells categorized into the above classifications to arrive at the percentage or frequency of each plugging event. The CRA followed up on that study and 152 wells were added to the original number to update the frequency. In 2003, 23 wells were plugged and abandoned in the New Mexico portion of the Delaware Basin. Three were ruled out because they were less than 2,150 feet deep. Twenty wells were categorized into one of the above plugging configurations and added to the count. For 2004, 25 wells were plugged and abandoned and all were added to the count. In 2005, 24 wells were plugged and abandoned but only 20 wells were used since two wells were shallow and two did not have any plugging reports available at the time of this report. The change indicated above is between the current and the CRA frequencies for each type of plugging configuration. 
TABLE 10

Seismic Activity in the Delaware Basin

\begin{tabular}{|c|c|c|c|c|c|}
\hline County & No. of Events & Earliest Event & Latest Event & $\begin{array}{c}\text { Smallest } \\
\text { Magnitude }\end{array}$ & $\begin{array}{c}\text { Largest } \\
\text { Magnitude }\end{array}$ \\
\hline Culberson & 9 & 12/30/1997 & $12 / 19 / 2003$ & 1 & 2.0 \\
\hline Eddy & 5 & 04/24/1983 & 12/03/1998 & 1.1 & 3.5 \\
\hline Lea & 1 & $04 / 24 / 2003$ & $04 / 24 / 2003$ & 2.0 & 2.0 \\
\hline Loving & 3 & 02/04/1976 & 04/28/1997 & 1.1 & 1.3 \\
\hline Pecos & 10 & 04/03/1977 & $12 / 22 / 1998$ & 1 & 2.2 \\
\hline Reeves & 16 & 08/03/1975 & $05 / 25 / 2002$ & 1 & 2.5 \\
\hline Ward & 26 & 09/24/1971 & 08/18/1984 & 0.8 & 3 \\
\hline Winkler & 1 & 04/30/1976 & 04/30/1976 & 1.5 & 1.5 \\
\hline TOTALS & 70 & & & & \\
\hline \multicolumn{6}{|l|}{$\begin{array}{l}\text { KEY: } \\
\text { Magnitude }\end{array}$} \\
\hline$\overline{\text { Less than } 2}$ & \multicolumn{5}{|c|}{ Very seldom ever felt } \\
\hline 2.0 to 3.4 & \multicolumn{5}{|c|}{ Barely felt } \\
\hline 3.5 to 4.2 & \multicolumn{5}{|c|}{ Felt as a rumble } \\
\hline 4.3 to 4.9 & \multicolumn{5}{|c|}{ Shakes furniture; can break dishes } \\
\hline 5.0 to 5.9 & \multicolumn{5}{|c|}{ Dislodges heavy objects; cracks walls } \\
\hline 6.0 to 6.9 & \multicolumn{5}{|c|}{ Considerable damage to buildings } \\
\hline 7.0 to 7.3 & \multicolumn{5}{|c|}{ Major damage to buildings; breaks underground pipes } \\
\hline 7.4 to 7.9 & \multicolumn{5}{|c|}{ Great damage; destroys masonry and frame buildings } \\
\hline Above 8.0 & \multicolumn{5}{|c|}{ Complete destruction; ground moves in waves } \\
\hline
\end{tabular}

NOTE: Three of the five earthquake events in Eddy County can be directly attributed to mining activities. The other two remain unexplained. Most of the seismic events recorded in the vicinity of the Delaware Basin can be attributed to oil and gas activities - such as the number of events that continue to occur in the Dagger Draw or Cass Ranch area of Central Eddy County (outside of the Delaware Basin) where a large number of oil and gas activities are being conducted. 


\section{TABLE 11}

Nine-Township Injection and SWD Well Information

\begin{tabular}{|c|c|c|c|c|c|c|c|}
\hline$\#$ & Location & API \# & Status & Injection Zone & Permitted & Last Injection & Cumulative Barrels \\
\hline 1 & 21S-31E-33 & $30-015-29330$ & SWD & $4,166-5,160$ & 1998 & April-2005 & $2,415,387$ \\
\hline 2 & 21S-32E-08 & $30-025-31412$ & SWD & $4,826-5,978$ & 1991 & April-2005 & $7,774,440$ \\
\hline 3 & 21S-32E-31 & $30-025-31443$ & SWD & 4,618-6,012 & 1992 & April-2005 & 174,327 \\
\hline 4 & 22S-30E-02 & $30-015-25758$ & Injection & $7,200-7,264$ & 1993 & April-2005 & $9,166,207$ \\
\hline 5 & 22S-30E-02 & $30-015-26761$ & Injection & $5,600-7,400$ & 1991 & April-2005 & $9,513,433$ \\
\hline 6 & 22S-30E-27 & $30-015-04734$ & SWD & 3,820-3,915 & 1981 & April-2005 & $2,878,664$ \\
\hline 7 & 22S-31E-02 & $30-015-32440$ & Injection & 6,989-7,020 & 2003 & April-2005 & 288,852 \\
\hline 8 & 22S-31E-24 & $30-015-26848$ & SWD & 4,519-5,110 & 1991 & April-2005 & $6,184,887$ \\
\hline 9 & 22S-31E-25 & $30-015-28281$ & Injection & $7,050-7,068$ & 1995 & April-2005 & $5,792,020$ \\
\hline 10 & 22S-31E-35 & $30-015-26629$ & SWD & $4,500-5,670$ & 1991 & April-2005 & $11,747,882$ \\
\hline 11 & 22S-31E-36 & $30-015-26171$ & SWD & $4,500-5,700$ & 1998 & April-2005 & 4,143,969 \\
\hline 12 & 22S-32E-05 & $30-025-27620$ & SWD & $5,150-8,602$ & 2004 & April-2005 & 590,590 \\
\hline 13 & 22S-32E-07 & $30-025-31076$ & SWD & $4,676-5,814$ & 1991 & April-2005 & $7,047,977$ \\
\hline 14 & 22S-32E-11 & $30-025-31716$ & SWD & $5,200-8,706$ & 1994 & April-2005 & $1,233,518$ \\
\hline 15 & 22S-32E-14 & $30-025-08113$ & SWD & 4,900-6,080 & 1994 & Dec-2003 & $3,808,585$ \\
\hline 16 & 22S-32E-16 & 30-025-31889 & SWD & $5,240-8,710$ & 1995 & April-2005 & $7,715,142$ \\
\hline 17 & 22S-32E-21 & 30-025-08109 & SWD & $4,755-5,110$ & 1992 & April-2005 & $2,443,663$ \\
\hline 18 & 22S-32E-27 & $30-025-32436$ & Injection & 6,831-8,388 & 1998 & April-2005 & 833,362 \\
\hline 19 & 22S-32E-28 & $30-025-31754$ & SWD & $4,690-5,800$ & 1993 & April-2005 & $2,145,371$ \\
\hline 20 & 22S-32E-31 & $30-025-20423$ & SWD & $4,662-5,915$ & 1993 & April-2005 & $3,850,490$ \\
\hline 21 & 22S-32E-31 & $30-025-32093$ & SWD & $4,590-5,626$ & 2004 & April-2005 & 232,801 \\
\hline 22 & 22S-32E-35 & 30-025-33149 & SWD & 4,950-6,252 & 1995 & April-2005 & $4,152,316$ \\
\hline 23 & 23S-30E-01 & $30-015-21052$ & SWD & $4,040-4,825$ & 2001 & April-2005 & $1,429,523$ \\
\hline 24 & 23S-30E-16 & 30-015-20899 & SWD & $4,433-5,952$ & 2002 & April-2005 & 241,233 \\
\hline 25 & 23S-30E-19 & $30-015-28901$ & SWD & $3,402-4,609$ & 1997 & March-2005 & 981,330 \\
\hline 26 & $23 S-30 E-20$ & $30-015-29549$ & SWD & $4,124-4,774$ & 2005 & No Report & No Report \\
\hline 27 & 23S-30E-29 & $30-015-28808$ & SWD & $5,479-7,220$ & 1996 & April-2005 & $2,233,760$ \\
\hline 28 & 23S-30E-33 & $30-015-31744$ & SWD & $4,546-6,760$ & 2002 & April-2005 & $1,936,044$ \\
\hline 29 & 23S-31E-02 & $30-015-05840$ & SWD & $4,489-5,670$ & 1997 & April-2005 & $6,331,577$ \\
\hline 30 & 23S-31E-02 & 30-015-29792 & SWD & $4,500-5,850$ & 1998 & April-2005 & $6,156,783$ \\
\hline 31 & 23S-31E-11 & $30-015-25419$ & SWD & $5,210-5,800$ & 2005 & April-2005 & 201,458 \\
\hline
\end{tabular}




\begin{tabular}{|c|c|c|c|c|c|c|c|}
\hline$\#$ & Location & API \# & Status & Injection Zone & Permitted & Last Injection & Cumulative Barrels \\
\hline 32 & 23S-31E-20 & $30-015-30605$ & Injection & $7,740-7,774$ & 2001 & April-2005 & 808,517 \\
\hline 33 & 23S-31E-26 & 30-015-20277 & SWD & $4,460-5,134$ & 1992 & Dec-2004 & $3,893,179$ \\
\hline 34 & 23S-31E-26 & 30-015-20302 & SWD & $4,390-6,048$ & 1971 & April-2005 & $5,435,068$ \\
\hline 35 & 23S-31E-27 & $30-015-27106$ & SWD & $4,694-5,284$ & 1998 & April-2005 & 4,839,641 \\
\hline 36 & 23S-31E-28 & $30-015-26194$ & SWD & $4,295-5,570$ & 1993 & April-2005 & $3,884,474$ \\
\hline 37 & 23S-31E-35 & $30-015-25640$ & SWD & $4,484-5,780$ & 1993 & April-2005 & $3,489,273$ \\
\hline 38 & 23S-31E-36 & 30-015-20341 & SWD & $5,980-6,560$ & 1994 & April-2005 & $10,027,613$ \\
\hline 39 & 23S-32E-04 & $30-025-31650$ & SWD & $4,884-5,886$ & 2001 & April-2005 & $2,242,287$ \\
\hline 40 & 23S-32E-14 & $30-025-26844$ & SWD & $5,496-6,014$ & 1991 & April-2005 & $1,197,044$ \\
\hline 41 & 23S-32E-23 & $30-025-33653$ & SWD & $5,954-6,064$ & 1999 & May-2001 & 912,470 \\
\hline 42 & 23S-32E-24 & 30-025-33521 & SWD & $5,925-6,042$ & 2000 & Sept-2004 & $1,439,434$ \\
\hline 43 & 23S-32E-29 & $30-025-31515$ & SWD & 4,844-4,944 & 1992 & April-2005 & $6,017,041$ \\
\hline 44 & 23S-32E-31 & $30-025-32868$ & SWD & $5,150-5,700$ & 1996 & Dec-2002 & 657,195 \\
\hline 45 & 23S-32E-36 & $30-025-31929$ & SWD & 5,364-6,138 & 1995 & April-2005 & $1,418,340$ \\
\hline
\end{tabular}

NOTE: Information collected from OCD offices in Artesia and Hobbs, New Mexico. Also, cumulative barrels information is collected from the Internet site maintained by the New Mexico Institute of Mining and Technology on behalf of the New Mexico Oil Conservation Division and from B. L. Resources of Hobbs, New Mexico. 
TABLE 12

Brine Well Status in the Delaware Basin

\begin{tabular}{|c|c|c|c|c|c|}
\hline County & Location & API \# & Well Name and No. & Operator & Status \\
\hline Eddy & 22S-26E-36 & $30-015-21842$ & City Of Carlsbad \#WS-1 & Key Energy Services & Brine Well \\
\hline Eddy & 22S-27E-03 & 30-015-20331 & Tracy \#3 & Ray Westall & $\begin{array}{l}\text { Plugged Brine } \\
\text { Well }\end{array}$ \\
\hline Eddy & 22S-27E-17 & $30-015-22474$ & Eugenie \#WS-1 & I \& W, Inc. & Brine Well \\
\hline Eddy & 22S-27E-17 & 30-015-23031 & Eugenie \#WS-2 & I \& W, Inc. & $\begin{array}{l}\text { Plugged Brine } \\
\text { Well }\end{array}$ \\
\hline Eddy & 22S-27E-23 & $30-015-28083$ & Dunaway \#1 & Mesquite SWD, Inc. & Brine Well \\
\hline Loving & Blk 29-03 & 42-301-10142 & Lineberry Brine Station \#1 & Chance Properties & Brine Well \\
\hline Loving & Blk 01-82 & $42-301-30680$ & Chapman Ford \#BR1 & Herricks \& Son Co. & $\begin{array}{l}\text { Plugged Brine } \\
\text { Well }\end{array}$ \\
\hline Loving & Blk 33-80 & $42-301-80318$ & Mentone Brine Station \#1D & $\begin{array}{l}\text { Basic Energy } \\
\text { Services }\end{array}$ & Brine Well \\
\hline Loving & Blk 29-28 & 42-301-80319 & East Mentone Brine Station \#1 & $\begin{array}{l}\text { Permian Brine Sales, } \\
\text { Inc. }\end{array}$ & $\begin{array}{l}\text { Plugged Brine } \\
\text { Well }\end{array}$ \\
\hline Loving & Blk 01-83 & 42-301-80320 & North Mentone \#1 & Chance Properties & Brine Well \\
\hline Reeves & Blk 56-30 & 42-389-00408 & Orla Brine Station \#1D & Mesquite SWD, Inc. & Brine Well \\
\hline Reeves & Blk 04-08 & 42-389-20100 & North Pecos Brine Station \#WD-1 & Chance Properties & Brine Well \\
\hline Reeves & Blk 07-21 & $42-389-80476$ & Coyanosa Brine Station \#1 & Chance Properties & Brine Well \\
\hline Ward & Blk 17-20 & 42-475-31742 & Pyote Brine Station \#WD-1 & Chance Properties & Brine Well \\
\hline Ward & Blk 01-13 & $42-475-34514$ & Quito West Unit \#207 & Seaboard Oil Co. & Brine Well \\
\hline Ward & Blk 34-174 & $42-475-82265$ & Barstow Brine Station \#1 & Chance Properties & Brine Well \\
\hline
\end{tabular}

